\title{
ZNALEZISKA WCZESNOŚREDNIOWIECZNYCH AKCESORIÓW KUPIECKICH Z SANTOKA NA TLE PORÓWNAWCZYM
}

\author{
FINDS OF EARLY MEDIEVAL TRADE ACCESSORIES FROM SANTOK \\ IN THE LIGHT OF COMPARATIVE STUDIES
}

\begin{abstract}
This article presents a collection of early medieval trade accessories, folded scales and weights excavated by archaeologists on site no. 1 in Santok (Lubusz province). The collection of weights is formally and chronologically diverse. The oldest specimens come from structures dated back to the $4^{\text {th }}$ quarter of the $9^{\text {th }}$ century, the youngest to the $14^{\text {th }}$ century. Metallographic analyses indicate that to produce the scales and weights, alloys of copper, different types of bronze and brass were used. The fact that exchange of goods in Santok took place earlier than in the other regions of Wielkopolska is evidence of close contacts with the then economic Baltic zone.
\end{abstract}

Keywords: Santok, early Middle Ages, weights, folded scales, trade, trader.

Akcesoria kupieckie, do których zalicza się wagi oraz odważniki, co rusz znajdowane są na stanowiskach $\mathrm{z}$ okresu wczesnego średniowiecza $\mathrm{z}$ terenu ziem polskich. Są to najczęściej znaleziska pojedynczych odważników lub części wag, a rzadziej całe zestawy lub wręcz komplety takich ciężarków (jeden z nielicznych przykładów takich kompletów to zespół odważników pochodzący ze stanowiska we Wrześnicy; Maleszka 1998). Przedmioty te występują w kontekście zarówno dawnych osiedli, grodów i osad otwartych, a także cmentarzy, jako wyposażenie grobowe zmarłych (przykład grobu z Sowinek - Krzyszowski 1997; Ciepłe - Kara 1998; Bodzia - Kara 2016). Również w trakcie prac archeologicznych na wczesnośredniowiecznym grodzisku w Santoku (woj. lubuskie, gm. loco) znaleziono fragmenty wag oraz odważniki różnego typu. Ośrodek w Santoku funkcjonował bardzo długo, bo przez ponad 600 lat. Początki zasiedlenia tego miejsca datowane są na 2 połowę VIII w., co wynika zarówno z ustaleń poczynionych na podstawie

* ORCID: 0000-0002-5752-1451; Instytut Archeologii i Etnologii PAN - Ośrodek Studiów Pradziejowych i Średniowiecznych, ul. Rubież 46, 61-612 Poznań, e-mail: kingamonczak@yahoo. 
analizy materiałów archeologicznych, jak i datowań bezwzględnych ${ }^{1}$ (Zamelska -Monczak 2009). W tym samym miejscu istniała najpierw osada otwarta, którą następnie rozbudowano do formy wieloczłonowego grodu ${ }^{2}$, aż ostatecznie w XIV i XV stuleciu obiekt ograniczono tylko do wieży, początkowo drewnianej, a następnie murowanej, kamienno-ceglanej, na kopcu wraz zapleczem (Kurnatowska 1995, s. 10-19).

Santok usytuowany jest w bardzo charakterystycznym miejscu, na styku trzech regionów geograficznych: Pomorza, środkowego Połabia i Wielkopolski, przy połączeniu dwóch dużych rzek: Warty i Noteci (ryc. 1). Lokalizacja ta miała niekwestionowany wpływ na kształtowanie obrazu kulturowego tego terytorium, gdzie krzyżowały się wpływy z różnych regionów, o odmiennych tradycjach kulturowych czy uwarunkowaniach gospodarczych i politycznych. Dotychczasowe wyniki badań wskazują, że osiedle założono jako punkt obsługi na wodnym szlaku komunikacyjnym i handlowym łączącym strefę nadbałtycką z interiorem, a jego rozwój był skorelowany z rytmem przemian zachodzących na sąsiednich obszarach (Zamelska-Monczak 2012, s. 372-373). Santok, oddalony od centrów regionów, był z nimi wręcz ściśle zintegrowany, poprzez ulokowanie przy głównym połączeniu wodnym.

Dotychczas w trakcie badań archeologicznych prowadzonych na grodzisku w Santoku, zarówno w obrębie tzw. podgrodzia, czyli rozległego członu warownego, który dolegał od wschodu do pierścieniowatego, odrębnie ufortyfikowanego tzw. grodu, jak i w obrębie wspomnianego grodu, pozyskano zbiór przyborów kupieckich liczący fragmenty trzech wag oraz dwadzieścia różnorodnych odważników (ryc. 2).

1 Wyniki datowań radiowęglowych metoda 14C AMS: próbka 1/07: 1210+/-30 BP - ADcal 690-900, prawdopodobieństwo 95,4\%; próbka 2/07: 1225+/-30 BP - ADcal 680-890, prawdopodobieństwo 95,4\%. Analizy wykonano w Poznańskim Laboratorium Radiowęglowym, zlecenie nr 2344/07.

${ }^{2}$ Zgodnie $\mathrm{z}$ genezą samego terminu, podgrodziem winno określać się osadę nieobronną położoną w sąsiedztwie grodu i tworzącą z nim strukturalną całość (Leciejewicz 1978, s. 54).

W przypadku stanowiska w Santoku w 2 połowie VIII wieku powstała osada otwarta, która w końcu IX stulecia została obwiedziona wałem drewniano-ziemnym. W 2 połowie X stulecia pobudowano kolejne umocnienia, tworząc następny segment, a ostatecznie obwałowano jeszcze jedną część, ale niestety datowanie tego odcinka umocnień nie zostało jeszcze ustalone. Ostatecznie powstał obiekt złożony z trzech segmentów.

Używane w niniejszym opracowaniu określenia: gród i podgrodzie są więc terminami umownymi, przyjętymi przez badaczy tego obiektu jeszcze w latach 50. Pod pojęciem gród (tzw. wewnętrzny) rozumiany jest najstarszy segment w obrębie kompleksu santockiego, którego początki sięgają końca IX stulecia. Natomiast jako podgrodzie traktowany jest obszar obejmujący strefę osadnictwa położoną na wschód i południowy zachód, poza obwałowaniami tego grodu. Relacja między poszczególnymi segmentami nie jest do końca wyjaśniona, gdyż nie wiemy, czy powstało od razu założenie dwuczłonowe czy trójczłonowe. Być może otwarte początkowo osadnictwo wokół grodu obwarowano dopiero po pewnym czasie, tworząc $\mathrm{w}$ ten sposób założenie wieloczłonowe. O kształcie ośrodka w Santoku w wieku XIII dowiadujemy się z Kroniki Wielkopolskiej, gdzie wymieniono jego dwa elementy „Były bowiem tam dwa grody, mniejszy, w którym książę zwykł przebywać, i większy, w którym rycerze mający [tam] miejsce schronienia przebywali z pospólstwem i rzemieślnikami”" (Kronika Wielkopolska 1965, s. 284). 


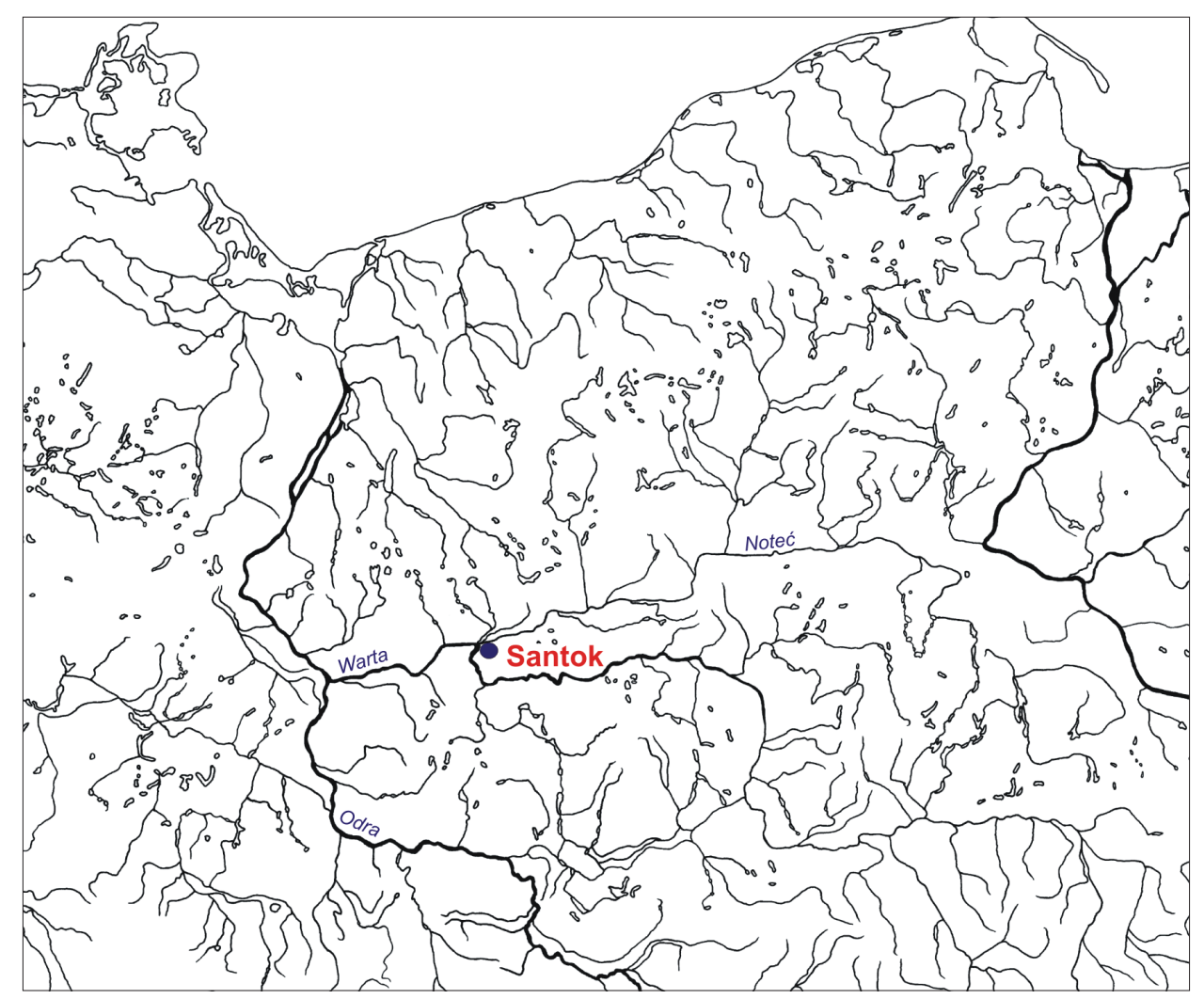

Ryc. 1. Lokalizacja Santoka na tle sieci rzecznej Wielkopolski i Pomorza. Oprac. K. Zamelska-Monczak

WAGI

W trakcie prac archeologicznych prowadzonych na grodzisku w Santoku w latach 1958-1965 znaleziono części trzech wag, a fragment kolejnego egzemplarza pozyskano podczas badań wykopaliskowych w 2016 roku. Żadna waga nie zachowała się więc w komplecie.

Ze strefy dawnego podgrodzia pochodzi ramię wagi składanej (nr inw. 130/16), częściowo złamane na jednym końcu, przy otworze na nit łączącym beleczkę z podstawą wskaźnika. Ramię wagi wykonano z pręta, w przekroju poprzecznym kolistego, o średnicy 3-4 mm (ryc. 3-1). Jest ono lekko, łukowato wygięte, a na końcach spłaszczone i rozszerzone w kształcie deltoidalnym, na końcu, gdzie przyłączano szalki, lub czworokątnym w miejscu łączenia z podstawą wskaźnika (ten koniec jest uszkodzony; odniesienia do analogicznych egzemplarzy wag pozwalają przypuszczać, że mógł on mieć kształt romboidalny). Na obu końcach przewier- 


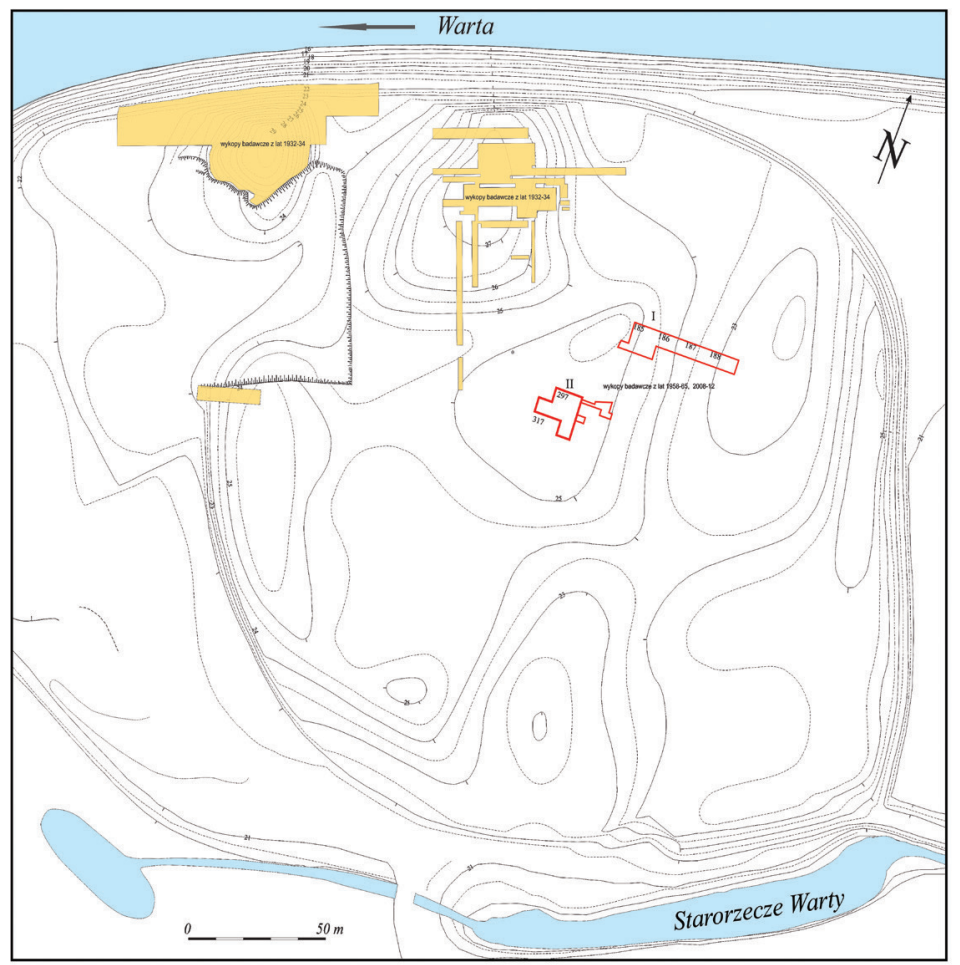

Ryc. 2. Plan warstwicowy grodziska w Santoku z zaznaczonymi wykopami archeologicznymi. Oprac. J. Sawicka

cono koliste otwory o średnicy $1,5 \mathrm{~mm}$. W zakończeniu beleczki znajduje się zgrubienie w postaci pięciu, połączonych ciasno dookolnych żłobków, przypominających karbowanie. Umieszczono je na granicy spłaszczonej końcówki z otworem do przymocowania szalek. Drugie rozszerzenie w obrębie ramienia ma formę kostki kubooktaedrycznej i zostało umieszczone na przeciwległym końcu, w miejscu gdzie rozpoczyna się zgrubienie prowadzące do zawiasa $\mathrm{z}$ otworem na nit mocujący z podstawą. Wymiary kostki to: długość $6 \mathrm{~mm}$, szerokość $5 \mathrm{~mm}$. Granice czterech ścianek kostki podkreślono puncowanymi liniami. Zachowana długość ramienia wynosi $5,7 \mathrm{~cm}$.

Badania metalograficzne odkrytego fragmentu wagi wykazały, że przedmiot ten odlano ze stopu składającego się w 82,08\% z miedzi, $8,38 \%$ z cynku i $0,58 \%$ z cyny, z dużym, prawie $8 \%$, dodatkiem ołowiu (tabela 1).

Forma i sposób wykonania beleczki pozwalają zaliczyć ją do wag typu 6.1 w typologii H. Steuera (1997, s. 230-236) albo typu I b w klasyfikacji K. Wachowskiego (1974, s. 187-188). W Europie Północnej, zwłaszcza w strefie nadbał- 
tyckiej, wagi takie były w użyciu od 2 połowy X do końca XI stulecia (Steuer 1997, s. 233-236; Abb. 169: 1-4). Waga analogiczna do santockiej została znaleziona ostatnio na Pomorzu Zachodnim w Żółtym na wyspie usytuowanej na Jeziorze Zarańskie (Chudziak 2014, s. 273; ryc. 6.140.a). Ten kompleks osadniczy, oddalony około $100 \mathrm{~km}$ na północny wschód od Santoka, dogodnie usytuowany na trakcie w kierunku Pomorza, funkcjonował od końca IX do schyłku XI w. (Chudziak, Kaźmierczak 2014, s. 451-453). Oprócz wagi znaleziono tam również szalki oraz zbiór odważników różnego typu.

Kolejna waga (nr inw. 261/58; ryc. 3-3) została znaleziona na skłonie dawnego wału wewnętrznego, w nawarstwieniach uformowanych w okresie, gdy umocnienia na tym odcinku nie pełniły już swojej funkcji obronnej, uległy częściowej niwelacji, a miejsce to wykorzystano na działalność gospodarczą. Część składanej wagi brązowej znaleziono wśród licznych przedmiotów metalowych, głównie zachowanych we fragmentach (w tym wycinek grawerowanej misy z mosiądzu, gwoździe, żużle, grudki rudy darniowej), zalegających w otoczeniu reliktów pieca do wytopu rudy oraz podwalin budynku, które są interpretowane jako pozostałość kuźni działającej w XIV wieku. Z wagi zachowała się belka - podstawa wskaźnika oraz dwie skrajne beleczki z końcówkami do mocowania szalek. Belka środkowa, w której mocowano imadełko, ma długość $45 \mathrm{~mm}$, jest w przekroju poprzecznym kolista. $\mathrm{Na}$ środku przebito kolisty otwór o średnicy $36 \mathrm{~mm}$ do mocowania, od dołu umieszczony w podłużnym wyżłobieniu długości $14,5 \mathrm{~mm}$. Ramiona utrzymujące szalki długości 9,6 cm i 9,5 cm są w przekroju poprzecznym koliste. Wykonano je techniką odlewania. Jedno z ramion uległo złamaniu w części zawiasowej. Na zakończeniach belek umieszczono kostki o ściętych narożnikach oraz koliste otwory, w których zachowały się kółeczka o średnicy $8 \mathrm{~mm}$ - ogniwa łańcuszka, służące do zawieszania szalek. Przeciwległe końce lekko rozszerzono i spłaszczono $\mathrm{w}$ formę trapezowatego zawiasu $\mathrm{z}$ otworami na nit mocujący ramiona $\mathrm{z}$ podstawą wskaźnika. Po rozłożeniu wagi ramiona osiągały długość całkowitą $21,5 \mathrm{~cm}$.

Ze wspomnianą wagą można łączyć uchwyt wykonany z brązu, zachowany częściowo, gdyż jeden koniec jest ułamany. Jego zachowana długość to $3,2 \mathrm{~cm}$, a największa szerokość na jednym z końców to $7 \mathrm{~mm}$. Uchwyt ma formę płaskiego, wydłużonego czworoboku, ozdobionego żeberkami, zwężonego z jednej strony i przechodzącego w kostkowe zakończenie. Łączny ciężar wagi to $46 \mathrm{~g}$.

Wagę wykonano $\mathrm{z}$ brązu cynowego. Udział miedzi w stopie wynosi prawie $90 \%$, a zawartość dodatków stopowych około $10 \%$, przy czym zawartość ołowiu jest dwa razy większa od cyny i cynku (tabela 1). Niski udział tych pierwiastków - około $2 \%$ - może wskazywać na wykorzystanie w procesie produkcji złomu brązowego uzupełnionego odpowiednio dużym wsadem ołowiu³.

\footnotetext{
${ }^{3}$ Analizę składu chemicznego metalu wykonano w Laboratorium Bio- i Archeometrii IAE PAN w Warszawie (nr laboratoryjny analizy CL 18298). Informacja pochodzi ze Sprawozdania z badań archeometrycznych. Stanowisko: Santok. Zlecenie Laboratorium Bio i Archeometrii $n r$ 1135/13 i 1166/2014, którego autorem jest Paweł Gan (dokumentacja w IAE PAN Ośrodek w Poznaniu).
} 
Tabela 1. Skład chemiczny stopów metali, z których wykonano wagi i powłoki odważników. Zawartość podana w procentach wagowych (analizy wykonano w Laboratorium Bio- i Archeometrii Instytutu Archeologii i Etnologii PAN)

\begin{tabular}{|c|c|c|c|c|c|c|c|c|c|}
\hline $\mathrm{Ni}$ & $\mathrm{Zn}$ & $\mathrm{As}$ & $\mathrm{Ag}$ & $\mathrm{Sn}$ & $\mathrm{Sb}$ & $\mathrm{Pb}$ & $\mathrm{Au}$ & $\mathrm{S}$ & $\mathrm{P}$ \\
\hline 0 & 3,47 & 0,6 & 0,39 & 2,44 & 0,25 & 6,91 & 0,09 & 0 & 0 \\
\hline 0 & 6,24 & 0,5 & 0,18 & 0 & 0 & 8,84 & 0,21 & 0 & \\
\hline 0 & 1,34 & 0,39 & 0,02 & 3,87 & 0 & 6,86 & 0 & 0 & \\
\hline 0 & 10,26 & 0 & 0 & 0,22 & 0,13 & 1,41 & 0 & 0 & 0 \\
\hline 0 & 3,68 & 0 & 0 & 0 & 0 & 5,4 & 0 & 3,4 & \\
\hline 0 & 8,93 & 0 & 0,09 & 2,41 & 0,38 & 2,71 & 0 & 0,03 & \\
\hline 0 & 8,48 & 0 & 0 & 0 & 0,21 & 9,54 & 0 & 0 & \\
\hline 0,12 & 15,72 & 0 & 0 & 0,87 & 0 & 1,52 & 0 & 0 & \\
\hline 0,04 & 13,63 & 0,54 & 0 & 0,35 & 0,08 & 13,53 & 0,1 & 0 & \\
\hline 0 & 9,33 & 0,47 & 0,1 & 2,28 & 0,13 & 7,13 & 0,2 & 0 & \\
\hline 0,06 & 8,38 & 0,16 & 0 & 0,58 & 0,09 & 7,86 & 0 & 0 & 0 \\
\hline 0,04 & 2,67 & 0,48 & 0 & 2,09 & 0,02 & 5,01 & 0,29 & 0 & \\
\hline 0 & 2,65 & 0,71 & 0 & 1,73 & 0,11 & 4,56 & 0,22 & 0 & \\
\hline 0,23 & 2,51 & 0,06 & 0,01 & 1,39 & 0,06 & 4,44 & 0,21 & 0,12 & \\
\hline
\end{tabular}

Wagę szalkową z Santoka można zaklasyfikować do typu $8 \mathrm{w}$ typologii Steuera (1997). Egzemplarze takie występują w Europie Środkowo-Zachodniej oraz Skandynawii od 2 połowy XI w., ale przede wszystkim w XIII, aż do XIV stulecia (Steuer 1997, s. 226-229).

W klasyfikacji K. Wachowskiego wagę te można przyporządkować do typu I b w (1974, s. 188), grupującego egzemplarze z ramionami zakończonymi jednym kostkowym zgrubieniem, o długości całkowitej po rozłożeniu nieprzekraczającej $20 \mathrm{~cm}$.

Z tym samym kontekstem znalezienia (zabytek z tej samej warstwy, lecz zalegający nieco głębiej), łączy się kolejny fragment wagi - tzw. imadełko (nr inw. 268/58). Przedmiot wykonano z cienkiej blachy i ozdobiono puncowaniem - wybijanymi oczkami (ryc. 3-2). Imadełko ma formę dwóch ramion symetrycznych, niezdobionych, połączonych na jednym końcu i rozklepanych. Wysokość imadełka (bez zawieszki z otworem) wynosi $6,5 \mathrm{~cm}$, szerokość na dole $0,45 \mathrm{~cm}$, a na górze $0,39 \mathrm{~cm}$. Ramiona są płasko rozklepane $\mathrm{w}$ dwóch płaszczyznach, pod kątem

Badania metalograficzne sfinansowano z programu Ministra Nauki i Szkolnictwa Wyższego pod nazwą „Narodowy Program Rozwoju Humanistyki” w latach 2012-2017. Tytuł projektu: Regni custodiam et clavem - Santok i clavis regni Poloniae - Milicz jako przykład dwóch grodów granicznych. Przygotowanie bazy źródłowej do przeprowadzenia archeologiczno-historycznego studium porównawczego" (nr 11H 11 018480. Kierownik projektu: prof. dr hab. Zofia Hilczer-Kurnatowska [2012-2013] oraz dr Kinga Zamelska-Monczak [2013-2017]). 


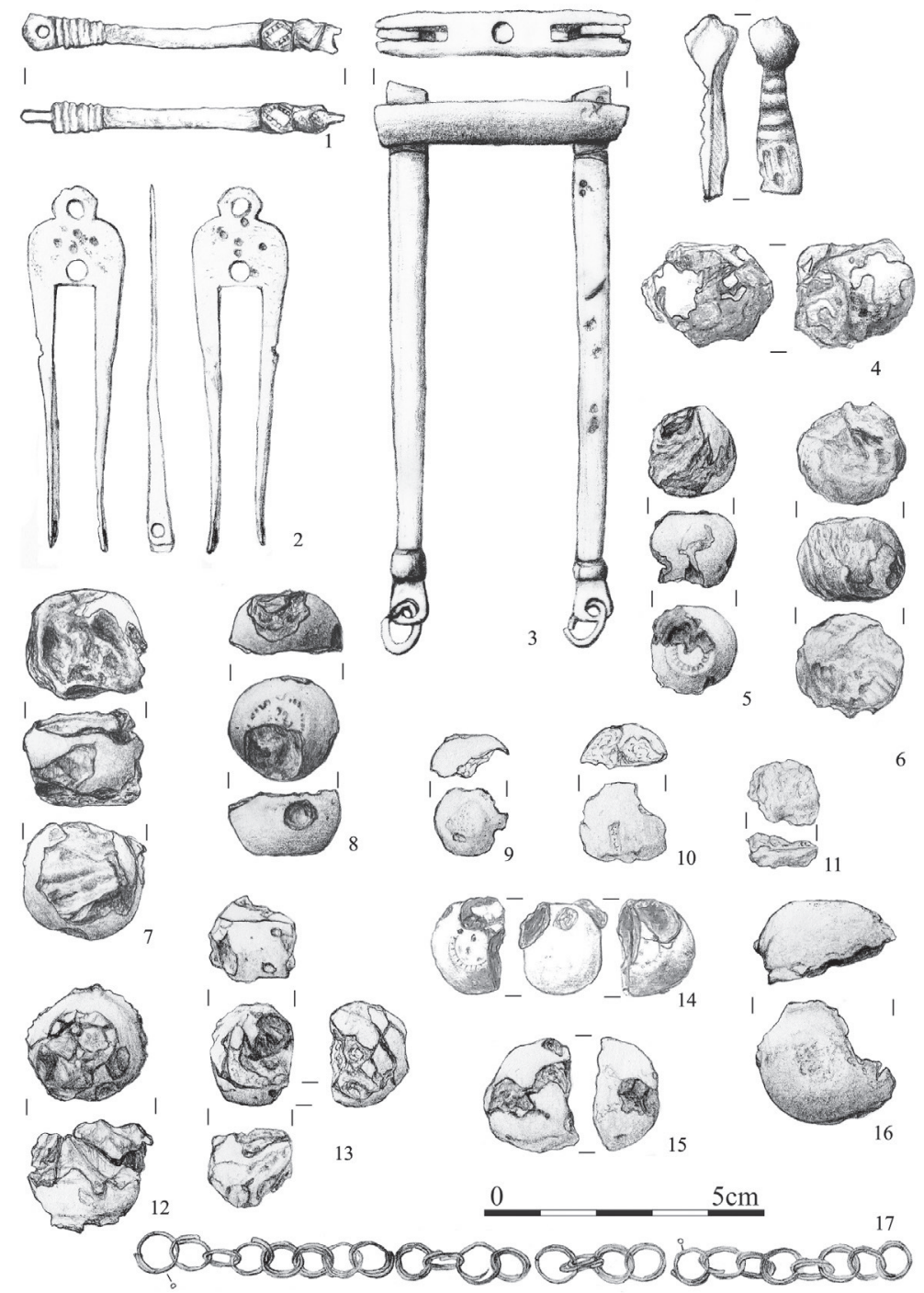

Ryc. 3. Santok, stan. 1. Wagi (1-3) i odważniki kuliste ze spłaszczonymi biegunami (4-16) oraz łańcuszek (17). Rys. A. Hurnowicz

90 stopni, co robi wrażenie skręcenia wokół własnej osi. Część szczytowa imadełka, płasko rozklepana w kształcie prostokąta z zaokrąglonymi narożnikami, zakończona jest $\mathrm{w}$ połowie szerokości kółkiem $\mathrm{z}$ otworem o średnicy $0,3 \mathrm{~cm}$. Między ramionami imadełka znajduje się kolisty otwór przebity centralnie w górnej, spłaszczonej części imadełka (to miejsce mogło też służyć do trzymania wagi) o średnicy $0,35 \mathrm{~cm}$. Na powierzchni górnej części imadełka, po obu jego stronach, 
wybito małe oczka, ale ich układ jest nieregularny (5-6 zagłębień na każdej stronie o średnicy $0,01 \mathrm{~cm}$ każde). Znaki to w tym przypadku raczej niewielkie koliste zagłębienia, odbiegające od typowych, wybijanych, regularnych oczek, które umieszczano na imadełkach (por. Steuer 1997, Abb. 155-158). Układ punktów nie jest przypadkowy, lecz nawiązuje do krzyża, czyli dwóch przecinających się linii. Analogiczna do santockiego kompozycja, ale wykonana z typowych oczek, znajduje się na imadełku znalezionym we Wrocławiu na ulicy Piaskowej, pochodzącym z egzemplarza datowanego na 1 połowę XIII w. (Wachowski 2002, ryc. 253-d) oraz na wagach z Kolonii, a także Mende z terenu dzisiejszych Węgier (Steuer 1997, Abb. 158-3, 5 i 153a-1).

Receptura surowca, z którego wykonano imadełko z Santoka, odbiega od użytego do produkcji znalezionej $\mathrm{w}$ sąsiedztwie wagi. Imadełko wycięto $\mathrm{z}$ blachy wykonanej z mosiądzu ołowiowego, który charakteryzuje skład: 79,59\% miedzi, $9,33 \%$ cynku, $7,13 \%$ ołowiu i $2,28 \%$ cyny $^{4}$. Charakterystyczny wyższy poziom cynku zwiększał wytrzymałość materiału i ułatwiał jego obróbkę mechaniczną (tabela 1). Nasuwa się pytanie, czy wszystkie części wag wykonywano z metalu o tym samym składzie, czy jednak używano surowca o różnych właściwościach w zależności od przeznaczenia i funkcji pełnionej przez daną część wagi.

Imadełko to ze względu na formę można zaliczyć do grupy 7 występującej z wagami szalkowymi typu 7 i 8 w typologii H. Steuera (1997, Abb. 114).

Mimo że waga i tzw. imadełko zostały znalezione w warstwie o tym samym pochodzeniu, a forma przedmiotów wskazuje, iż mogły powstać i być użytkowane w tym samym czasie, nie można jednoznacznie stwierdzić, iż są to części pochodzące $\mathrm{z}$ tego samego egzemplarza.

Rozpatrując funkcję i chronologię tych zabytków, szczególną uwagę należy zwrócić na kontekst tego znaleziska. Jak wspomniano wcześniej, analizowane części wagi zalegały w nawarstwieniach łączonych z reliktami kuźni funkcjonującej na wschodnim, dość silnie zniwelowanym wale grodu tzw. wewnętrznego. Znaleziono je w warstwie powiązanej z tym obiektem, wśród wielu innych przedmiotów metalowych, zachowanych głównie we fragmentach (w sumie prawie 50 przedmiotów żelaznych i brązowych: gwoździe, noże, haki, siekiery, blachy i misy żelazne, klucze, wagi oraz bryłki żelaza, żużla i rudy). Na podstawie ustaleń stratygraficznych i materiału archeologicznego kuźnię w Santoku można datować na XIV stulecie. Wówczas w miejscu dawnego wieloczłonowego grodu, w jego północno-zachodniej części, funkcjonowała tylko wieża obronna na kopcu, a miejsce domniemanej kuźni znajdowało się w odległości około $150 \mathrm{~m}$ na wschód od tego budynku. Fragmenty wag odkryte w warstwie zawierającej relikty kuźni mogą być powiązane z procesem wtórnej obróbki metalowych przedmiotów, poddawanych w tym miej-

\footnotetext{
${ }^{4}$ Analizę składu chemicznego metalu wykonano w Laboratorium Bio- i Archeometrii IAE PAN w Warszawie (nr laboratoryjny analizy CL 18300). Informacja pochodzi ze Sprawozdania z badań archeometrycznych. Stanowisko: Santok. Zlecenie Laboratorium Bio i Archeometrii $n r$ 1135/13 i 1166/2014, którego autorem jest Paweł Gan (dokumentacja w IAE PAN - Ośrodek w Poznaniu).
} 


\begin{tabular}{|c|c|c|c|c|c|c|c|c|c|c|c|c|c|c|c|c|c|}
\hline 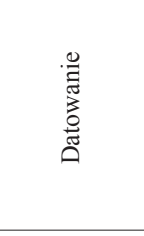 & $\begin{array}{l}3 \\
\vec{x}\end{array}$ & , & 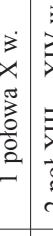 & 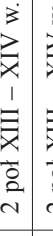 & & 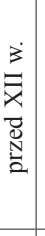 & a. & a. & & , & $\begin{array}{l}3 \\
\bar{x}\end{array}$ & $\frac{\dot{B}}{\bar{x}}$ & 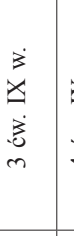 & & & & 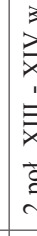 \\
\hline 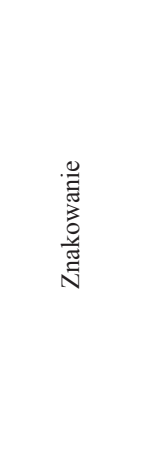 & 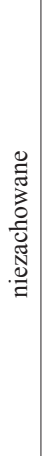 & 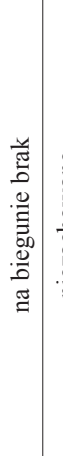 & 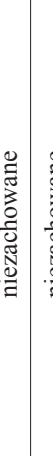 & 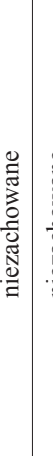 & 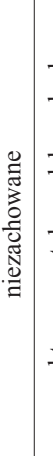 & 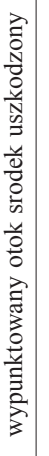 & 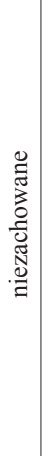 & 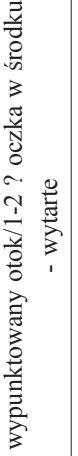 & 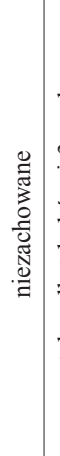 & 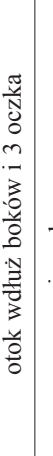 & 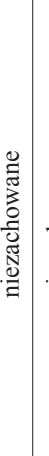 & 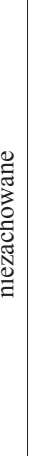 & & & & & \\
\hline 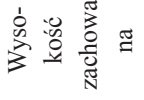 & \pm & $\begin{array}{ll}n \\
m & =\end{array}$ & $\cong$ & $\because 2$ & 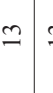 & $\cong$ & $\begin{array}{l}n \\
= \\
=\end{array}$ & $=$ & $\begin{array}{l}n \\
\stackrel{\sim}{ \pm}\end{array}$ & $r$ & $\simeq$ & ते & $a^{2}$ & & & & in \\
\hline $\begin{array}{l}\text { बे } \\
\text { 产自 } \\
\dot{z}\end{array}$ & ন & $\stackrel{\infty}{-}$ & $\vec{\sim}$ & $\vec{\lambda}$ & ते. & 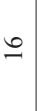 & $\pi$ & $\approx$ & $\begin{array}{ll}n \\
0^{2}\end{array}$ & $r$ & 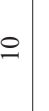 & & $\simeq$ & $\pi$ & & & 工 \\
\hline 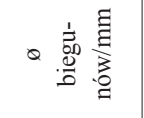 & 0 & $r$ & $\approx s$ & 90 & $\sigma$ & 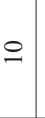 & 0 & $=$ & $=$ & r & & & & & & & \\
\hline 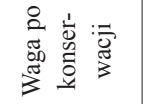 & & $\stackrel{3}{=}$ & $\hat{m}$ & $\stackrel{\dot{m}}{\mathrm{~m}}$ & $\stackrel{2}{\hat{e}^{2}}$ & $\vec{\infty}$ & di & $\stackrel{\infty}{=}$ & $\overrightarrow{\mathrm{i}}$ & $\vec{i}$ & $?$ & $\vec{n}$ & $\stackrel{n}{n}$ & $\begin{array}{l}n \\
n \\
n \\
2\end{array}$ & $\mathrm{v}$ & $f$ & $\overline{7}$ \\
\hline 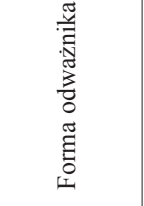 & 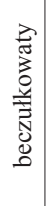 & 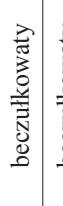 & 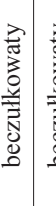 & 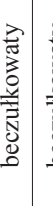 & 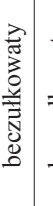 & 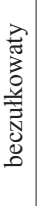 & 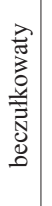 & 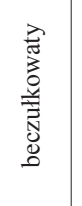 & 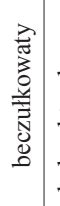 & 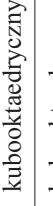 & 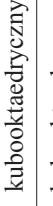 & 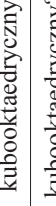 & $=$ & & & & 要 \\
\hline 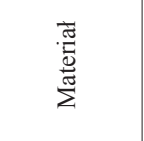 & 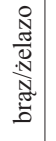 & 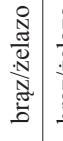 & 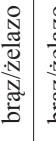 & 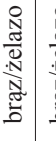 & 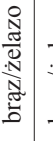 & 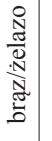 & 胥 & 遥 & 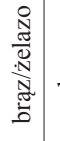 & 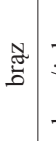 & $\begin{array}{l}\frac{8}{2} \\
\frac{2}{2} \\
\frac{d}{2} \\
\frac{y}{2}\end{array}$ & 总 & 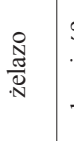 & : & 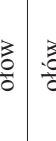 & $\frac{5}{2}$ & $\frac{0}{0}$ \\
\hline 着 & 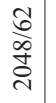 & 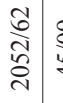 & 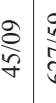 & तु & 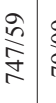 & ڤু & $\varangle$ & $\infty$ & 0 & 离 & 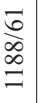 & $\begin{array}{ll}\vec{b} \\
\infty \\
= \\
= \\
=\end{array}$ & 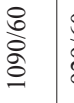 & 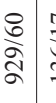 & 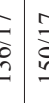 & 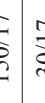 & \\
\hline
\end{tabular}


scu naprawie albo przetwarzanych na całkiem nowe wyroby. Nie jest wykluczone, że waga szalkowa była przyrządem używanym podczas procesu przetapiania i obróbki metali, służąc metalurgowi do odważania składników niezbędnych do przygotowania odpowiedniego stopu zgodnie $\mathrm{z}$ określoną recepturą.

Do kategorii przedmiotów związanych $\mathrm{z}$ wagami można $\mathrm{z}$ dużym prawdopodobieństwem zaliczyć także fragmenty łańcuszka wykonanego z brązu (nr inw. 2256/64), na którym zawieszano szalki (ryc. 3-17). Łańcuszek znaleziono we wnętrzu grodu, w warstwie datowanej na 2 połowę XI-XII stulecie. Zachowały się trzy fragmenty łańcuszka o długości $\mathrm{w}$ sumie $13,5 \mathrm{~cm}$. Jego konstrukcja opiera się na spleceniu poprzez przewleczenie ogniw o średnicy zewnętrznej około 6-7 $\mathrm{mm}$, zwiniętych z dwóch zwojów cienkiego drutu o przekroju średnicy $0,7-0,8 \mathrm{~mm}$. Na grodzisku w Santoku nie znaleziono do tej pory szalek, nieodłącznych elementów wag składanych, ani żadnych ich fragmentów.

\section{ODWAŻNIKI}

Ważenie ciężaru na wadze szalkowej wymagało posiadania odpowiednich akcesoriów, czyli odważników, za które uważa się przedmioty najczęściej z metali, o precyzyjnie wyznaczonym ciężarze. Zbiór odważników znalezionych w nawarstwieniach grodziska w Santoku liczy 20 egzemplarzy, z czego funkcja dwóch nie jest ewidentna. Zestaw jest bardzo zróżnicowany pod względem formalnym oraz surowcowym. Najlepiej, bez jakichkolwiek uszczerbków, zachowały się odważniki z ołowiu oraz pojedynczy okaz z brązu. Pozostałe noszą ślady uszkodzeń i korozji, stąd problematyczne jest określenie ich pierwotnego ciężaru, a także odczytanie oznakowania. Odważniki znajdowano w nawarstwieniach zarówno dawnego grodu, jak i podgrodzia. Prawie $1 / 3 \mathrm{z}$ nich pochodzi jednak z warstwy ornej i nie można określić pierwotnej lokalizacji i kontekstu ich znalezienia (parametry i kontekst znalezienia wszystkich odważników zawarto w tabeli 2).

Odważniki santockie można podzielić według kryterium formalnego na kilka grup, odwołując się do powszechnie stosowanego w literaturze naukowej podziału zaproponowanego przez H. Steuera (1997). Zgodnie z tą typologią w Santoku reprezentowane są odważniki kubooktaedryczne (grupa A według Steuera) i kuliste ze spłaszczonymi biegunami (inaczej beczułkowate; grupa B), a także cylindryczne i stożkowate $\mathrm{z}$ ołowius .

\footnotetext{
${ }^{5}$ Grupy wydzielone przez H. Steuera (1997) bazują na podziale, który zaproponował Ola Kyhlberg dla odważników znalezionych w Birce (Kyhlberg 1986); typ A - kubooktaedryczne to odpowiednik grupy B według O. Kylhberg, typ B - kuliste ze spłaszczonymi biegunami odpowiadają grupie A; odważniki ołowiane $\mathrm{O}$. Kylhberg podzielił na grupy: C - cylindryczne oraz E - stożkowate i dwustożkowate.
} 


\section{ODWAŻNIKI KULISTE ZE SPŁASZCZONYMI BIEGUNAMI}

Wśród znalezisk santockich najliczniej reprezentowane są odważniki kuliste ze spłaszczonymi biegunami, a ich zbiór liczy 11 takich odważników. Wszystkie wykonano w podobny sposób, z żelaznego jądra pokrytego cienką powłoką, tzw. koszulką, z brązu.

Z osadnictwem we wnętrzu grodu można łączyć trzy odważniki o takiej formie. Najstarszy z nich pochodzi z poziomu osadniczego datowanego na 1 połowę $\mathrm{X}$ w. (nr inw. 45/09). Zabytek zachował się tylko częściowo, gdyż korodujące żelazne jądro rozsadziło powłokę z brązu (ryc. 3-12). Zachowany ciężar odważnika to obecnie $14,7 \mathrm{~g}$, ale uwzględniając ubytki, mógł on ważyć około 20 g. Niestety, niemożliwe jest dziś ustalenie, czy był to egzemplarz znakowany na biegunach.

Kolejne dwa odważniki beczułkowate pochodzą z młodszych nawarstwień grodu, datowanych na 2 połowę XI-XII w. i również przetrwały w części. Na jednym z tych odważników (nr inw. 79/09) zachowała się dobrze duża część jednego z biegunów, na którym widoczny jest fragment wypunktowanego otoku oraz część oczka w środku (ryc. 3- 5). Drugi ze wspomnianych egzemplarzy (nr inw. 75/16) należał do większych okazów, gdyż jego średnica w najbardziej wypukłym miejscu to $22 \mathrm{~mm}$, przy zachowanym ciężarze 22,2 g (ryc. 3-4). Nie wiemy dziś, jakie było ich znakowanie.

Spośród ośmiu odważników beczułkowatych znalezionych w strefie podgrodzia (nr inw. 627/59, 747/59, 2048/62, 2052/62) połowa pochodzi z poziomów datowanych na XIII i XIV w., czyli należą one do młodszego horyzontu osadniczego wydzielonego w obrębie grodu santockiego. Cztery okazy to znaleziska luźne. Wszystkie odważniki są mocno zniszczone. Przetrwały jedynie części koszulek z brązu i skorodowane fragmenty żelaznych jąder. Jeden z odważników (nr inw. 627/59; ryc. 3-16) zalegał $\mathrm{w}$ nawarstwieniach łączonych $\mathrm{z}$ pozostałościami wspomnianej już wcześniej kuźni, w których znaleziono również składaną wagę i imadełko. Odważnik znaleziony w tym kontekście mógł stanowić wyposażenie kuźni jako instrument do odważania surowca (?) albo uszkodzony (wadliwy?, niepotrzebny?) przedmiot został potraktowany jako złom do przetopienia. Wspomniany odważnik miał zachowany jeden biegun o średnicy $10 \mathrm{~mm}$, nieoznakowany.

Kolejny odważnik beczułkowaty (ryc. 3-15), zachowany w małym fragmencie (nr inw. 747/59), pochodzi z warstwy utworzonej na wyniesieniu wału w okresie poprzedzającym pojawienie się tam obiektów pełniących funkcje gospodarcze, datowanych na XIV stulecie. Ten okaz cechuje obecność lekko wklęsłego bieguna. $\mathrm{Z}$ konkretnymi budynkami drewnianymi usytuowanymi w części podgrodzia można powiązać dwa odważniki beczułkowate. Egzemplarz z chaty oznaczonej numerem 7 (nr inw. 2052/62) miał średnicę maksymalną $18 \mathrm{~mm}$ i jeden zachowany biegun bez widocznych oznaczeń (ryc. 3-13). Z drugiego odważnika (nr inw. 2048/62), odsłoniętego w chacie nr 1, zachował się jedynie fragment silne zniszczonej ko- 
szulki z brązu (ryc. 3-9). Odważniki te znaleziono w obiektach datowanych na wiek XII.

Miejsce znalezienia czterech odważników kulistych o spłaszczonych biegunach nie jest precyzyjnie określone. Dwa z nich miały oznakowane bieguny w postaci wypunktowanego otoku oraz mocno wytartego jednego (być może dwa?) oczka wewnątrz. Odważniki te są bardzo zbliżone pod względem wielkości: największa średnica mieści się w przedziale 16,8-19 mm, a biegunów 10,08-11,8 mm, przy obecnym ciężarze 10,1-11,8 g, co przy zachowanej połowie ich wielkości wskazuje na dwukrotnie większą wagę pierwotną. Podobne parametry wielkościowe jak wspomniane okazy oznakowane miał kolejny odważnik z grupy luźno znalezionych na podgrodziu. Natomiast czwarty egzemplarz z tej grupy cechują już większe rozmiary oraz ciężar $22,4 \mathrm{~g}$, przy stanie zachowania około $2 / 3$ wielkości.

Dla ośmiu odważników beczułkowatych przeprowadzono analizę metalograficzną tzw. koszulek pokrywających żelazne ,jądra" je ze stopu miedzi z innymi pierwiastkami (tabela 1). Udział miedzi w stopie waha się między $85,82 \%$ a $78,33 \%$ (udział podany w procentach wagowych), natomiast rodzaj oraz wkład innych pierwiastków był bardzo zróżnicowany, można więc powiedzieć, że były to zarówno brązy, jak i różne gatunki mosiądzu. Dominującymi dodatkami były: cynk, cyna i ołów, a im większa była zawartość cyny lub cynku, tym uzyskany stop był twardszy. Historia produkowania stopów mosiężnych sięga starożytności, ale technologia ta rozwinęła się przede wszystkim w okresie wczesnego cesarstwa rzymskiego. Za obszar o najstarszych tradycjach produkcji wyrobów z mosiądzu uznaje się obecnie Indie, natomiast na rozwój tej wytwórczości w Europie wpływ miał sposób produkcji brązu praktykowany w Egipcie, skąd umiejętność ta dotarła na teren cesarstwa rzymskiego (Tomaszewska-Szewczyk 2016, s. 19). W średniowieczu, w Europie Zachodniej, metoda sporządzania mosiądzu była nadal udoskonalana, ale podstawą jej rozwoju były ośrodki produkcji o tradycji antycznej. Z biegiem czasu rozwijała się także lokalna wytwórczość, czego przykładem z ziem polskich jest metalurgia poświadczona w ośrodku w Kruszwicy (Tomaszewska-Szewczyk 2016, s. 25-28).

Powłoki sześciu odważników z Santoka cechuje wysoki udział cynku w stopie, w ilości od 3,68\% do $15,72 \%$, co wskazuje, że wykonano je z mosiądzu. W czterech przypadkach zanotowano, że dodatkowi cynku towarzyszy również widoczny udział ołowiu (między 1,41\% do 8.84\%), co pozwala określić stop użyty do produkcji koszulek jako mosiądz ołowiowy (tabela 1). Zresztą dodatek tego pierwiast-

\footnotetext{
${ }^{6}$ Analizę składu chemicznego metalu wykonano w Laboratorium Bio- i Archeometrii IAE PAN w Warszawie (nr laboratoryjny analizy CL 16423, 18302, 18306, 18839, 19561, 19566; dokumentacja w IAE PAN Ośrodek w Poznaniu). Badania metalograficzne CL 19561 oraz CL 19566 sfinansowano z projektu Narodowego Centrum Nauki - konkurs Sonata Bis 5 nr 2015/18/E/HS3/00425 „Człowiek a środowisko - warunki przyrodnicze i charakter antropopresji pogranicza Wielkopolski i Pomorza we wczesnym średniowieczu w świetle badań geoarcheologicznych kompleksu osadniczego w Santoku" (kierownik dr Kinga Zamelska-Monczak).
} 
ka w ilości od $1,41 \%$ do $9,54 \%$ jest obecny we wszystkich analizowanych powłokach. Dodatek ołowiu do stopu ułatwiał przede wszystkim formowanie koszulki na żelaznym jądrze, niestety, jednocześnie wpływał na zwiększenie ciężaru odważnika.

W składzie pierwiastków trzech metalowych koszulek zarejestrowano ponad $2 \%$ udział cyny. Na podstawie składu stopu o dwóch z nich można powiedzieć, że prezentują cechy charakterystyczne dla brązu ołowiowego.

Stopy zawierały także drobne ilości innych pierwiastków, takich jak krzem, tytan, mangan, antymon, arsen, żelazo, nikiel czy siarka, których obecność może być wynikiem zanieczyszczeń samej rudy miedzi. W dwóch koszulkach zanotowano znikomą zawartość złota. Zróżnicowanie składów stopów miedzi, z których wykonano powłoki pokrywające żelazne jądra odważników, jest bardzo duże i nie uwidaczniają się wyraźne tendencje ułatwiające wskazanie miejsca pochodzenia surowców. Wykorzystywanie mosiądzu ołowiowego w produkcji koszulek odważników jest przesłanką, że dane egzemplarze wykonano w skandynawskich warsztatach metalurgicznych, gdzie te tradycje były obecne. Typowym stopem tam używanym była miedź $\mathrm{z}$ dodatkiem cynku, ołowiu i minimalnym udziałem, lub całkowitym brakiem, cyny (Wärmländer, Zoric, Byockd i Scots 2010, s. 2287). Gotowy mosiądz docierał do Skandynawii z pracowni zachodnioeuropejskich w postaci specjalnych zestandaryzowanych sztabek (Sindbæk 2001, s. 58-59; Söderberg, strona www).

Odważniki kuliste ze spłaszczonymi biegunami, zwane także beczułkowatymi lub sferycznymi, znane są z wielu wczesnośredniowiecznych stanowisk, skupionych głównie wokół Morza Bałtyckiego i Północnego i z terenu Rusi oraz, mniej licznie, strefy Niżu Polskiego, głównie Pomorza, Wielkopolski oraz Śląska. Najwięcej znalezisk różnych typów odważników, nie tylko kulistych ze spłaszczonymi biegunami, kumuluje się $\mathrm{w}$ ośrodkach ściśle powiązanych $\mathrm{z}$ handlem dalekosiężnym, czego ilustracją jest osiedle Truso, gdzie pozyskany w trakcie badań archeologicznych zbiór liczy ponad 1000 egzemplarzy (Jagodziński 2010, s. 141, przypis 186; Steuer 2012, s. 191), Kaupang w Norwegii, gdzie zidentyfikowano ponad 400 odważników o różnych formach (Pedersen 2008, s.123), także w Birce znaleziono ponad 700 okazów, w trakcie wszystkich lat badań, z czego część pochodzi z cmentarzyska (Gustin 2004, s. 22). Wagi i odważniki występują tam zarówno na terenie osad, jak i w grobach, na cmentarzyskach.

Odważniki kuliste ze spłaszczonymi biegunami znalezione na stanowisku w Santoku to na powyższym tle niezbyt liczny zbiór, 11 egzemplarzy, z których niestety prawie połowa to znaleziska luźne $\mathrm{z}$ warstwy humusu. Stan zachowania zabytków nie pozwala niestety na przeprowadzenie dokładnej analizy metrycznej, określenie pierwotnej wagi czy wnioskowanie na temat ewentualnego znakowania umieszczonego na biegunach. Uwidaczniają się natomiast różnice w proporcjach: stosunku wysokości do największej średnicy oraz w średnicach biegunów. Klasyfikację odważników, która jest obecnie uznana i stosowana wśród archeologów, 
zaproponował H. Steuer (1997), a na gruncie polskim pewne weryfikacje do niej, uwzględniające specyfikę lokalną, wprowadził K. Wachowski (2006). Zasadniczy podział opiera się na kryterium formy i surowca, z którego odważnik został wykonany. Znalezione w Santoku i przedstawione powyżej kuliste odważniki ze spłaszczonymi biegunami, można (wskazówki uzyskane na podstawie formy, proporcji wysokości do biegunów oraz wielkości, przy szczątkowo zachowanym znakowaniu) zaklasyfikować do typu B wyróżnionego przez H. Steuera, z dużym prawdopodobieństwem do podtypów 1 oraz 2, wydzielonych w jego obrębie (1997, s. 44-47).

Odważniki z grupy B 1 (z rozróżnieniem na wczesne/średnie/późne) charakteryzują się większą średnicą biegunów oraz mniejszą wysokością niż okazy reprezentujące typ B 2 (średnice maksymalne w przypadku obu typów są porównywalne). Spośród okazów santockich do grupy B 1 można zaliczyć cztery odważniki (o numerach inwentarza 45/09 i 79/09 oraz dwa luźno znalezione: B i C). Wszystkie pochodzą z obrębu grodu tzw. wewnętrznego, niestety, tylko jeden ma określony bliższy kontekst: zalegał $\mathrm{w}$ spalonych reliktach ścianki obiektu datowanego na 1 połowę $\mathrm{X}$ wieku. Średnice maksymalne odważników mieszczą się w przedziale od 15,9 mm do 19,6 mm. Dwa w tej grupie noszą ślady znakowania na biegunach, zachowane fragmentarycznie w postaci części otoku i jednego oczka. Wszystkie wspomniane odważniki zostały powleczone warstwą stopu miedzi z dużą zawartością cynku oraz ołowiu, którego dodatek przewyższał w trzech przypadkach udział cynku (odważniki nr 45/09 i 79/09 oraz B; tabela 1).

Odważniki B 1 uważane są za starsze formy niż B 2 i wskazuje się schyłek IX w. jako początek ich występowania na stanowiskach. Formy starsze (,B 1 alt”) i środkowe („,B 1 - mittel”) występują jeszcze przez cały wiek X i XI, natomiast młodsze („B 1 - jung”) znane są do połowy XIII stulecia (Steuer 1997, Abb. 232).

Do typu B 2 odważników można natomiast zakwalifikować 4 santockie egzemplarze (o numerach inwentarza: 2052/62, 747/59, 627/59 i 131/16). Wszystkie pochodzą z terenu tzw. podgrodzia, z poziomów osadniczych datowanych na XIII wiek. Jeden $\mathrm{z}$ odważników został znaleziony $\mathrm{w}$ warstwie humusu. W wynikach analizy metalograficznej widoczne są różnice $\mathrm{W}$ składzie stopu pokrywającego żelazny rdzeń w stosunku do okazów typu B 1 . W powłoce odważników B 2 jest między $83 \%$ a $86 \%$ udział miedzi, duży dodatek ołowiu: prawie $7 \%$, oraz cyny: $2,44-3,87 \%$, a najmniejszy cynku: $1,34-3,47 \%$, co w sumie zbliża ten stop raczej do kategorii brązów ołowiowych?

Na biegunach dwóch odważników tego typu przetrwały fragmenty oznakowania - zachowany częściowo otok oraz dwa oczka. Niestety, na żadnym z egzemplarzy

\footnotetext{
${ }^{7}$ Informacja ze Sprawozdania z badań archeometrycznych. Stanowisko: Santok. Zlecenie Laboratorium Bio- $i$ Archeometrii $n r$ 1135/13, którego autorem jest Paweł Gan (dokumentacja w IAE PAN - Ośrodek w Poznaniu).
} 
nie jest widoczny pełen układ oznaczeń. Wielkość odważników typu B 2 jest mocno zróżnicowana, a ich maksymalne średnice mieszczą się w przedziale od 16,8 mm do $25 \mathrm{~mm}$.

Trudne jest także oszacowanie ciężaru pierwotnego tych odważników, ze względu na silnie zaznaczoną korozję rdzenia i uszkodzenie zabytków.

K. Wachowski włącza powyższe okazy do II systemu zwanego słowiańskim, porządkującego odważniki z ziem polskich według kryterium formy i znakowania oraz technologii (2006, s. 359-360). System II obejmuje według tego autora odważniki beczułkowate wyższe i o większej średnicy biegunów w stosunku do form B $1 \mathrm{H}$. Steuera. Znakowanie biegunów ograniczone jest tu do otoku oraz czterech kółek wewnątrz, i co istotne, uwzględnione są w tym systemie także okazy całkowicie pozbawione znakowania.

H. Steuer datuje odważniki grupy B 2 na okres od początków XI do przełomu XII i XIII, a nawet połowy XIII stulecia $\mathrm{i}$ do horyzontu tego wpisywałyby się odważniki z podgrodzia santockiego (Steuer 1997, Abb. 232).

\section{ODWAŻNIKI KUBOOKTAEDRYCZNE}

W nawarstwieniach kulturowych grodziska santockiego znaleziono cztery egzemplarze odważników o formie tzw. kubooktaedrycznej, czyli sześcianów ze ściętymi narożnikami, co dawało w efekcie bryłę o sześciu czworokątnych i ośmiu trójkątnych ściankach (sześcio-ośmiościan). Najmniejszy z odważników kubooktaedrycznych (nr inw. 16/11; ryc. 4-1) pochodzi z nawarstwień obiektu w kształcie pagórka (kurhanu?) odsłoniętego we wnętrzu grodu. Miał on postać nasypu ogrodzonego drewnianymi ściankami i usytuowany był poniżej kamiennego fundamentu niezachowanej budowli, której relikty łączyć można $\mathrm{z}$ okresem 2 połowy $\mathrm{X}$ i 1 połową XI stulecia. Obiekt ten, o formie kurhanu, zalegał na warstwie silnie sprasowanej mierzwy, w układzie stratygraficznym odpowiadającej IV poziomowi osadniczemu wydzielonemu we wnętrzu grodu, datowanemu, na podstawie ustaleń stratygraficznych i analizy materiałów archeologicznych, na 4 ćwierć IX wieku. Przeprowadzone analizy 14C AMS drewna z ogrodzenia wspomnianego nasypu potwierdzają takie datowanie, sytuując jego funkcjonowanie $\mathrm{w}$ przedziale koniec IX-1 połowa $\mathrm{X}$ wieku .

\footnotetext{
8 Próbka Santok 5/12 - ogrodzenie północne - 1145 +/-25 BP: 875-915 AD prawdopodobieństwo 68,2\%, w tym 915-969 AD na poziomie ufności 45\%; 781-975 AD, prawdopodobieństwo 95,4\%, w tym 808-975AD na poziomie ufności 93,1\%.

Próbka Santok 87/11 - ogrodzenie południowe - 1140 +/-30 BP: 879-971 AD prawdopodobieństwo 68,2\%, w tym 912-971 AD na poziomie ufności 48,2\%; 781-982 AD, prawdopodobieństwo 95,4\%, w tym 808- 982 AD na poziomie ufności 93,2\%.

Analizy wykonano w Poznańskim Laboratorium Radiowęglowym metodą akceleratorową (numery laboratoryjne prac: 6811/12 oraz 6089/11).
} 

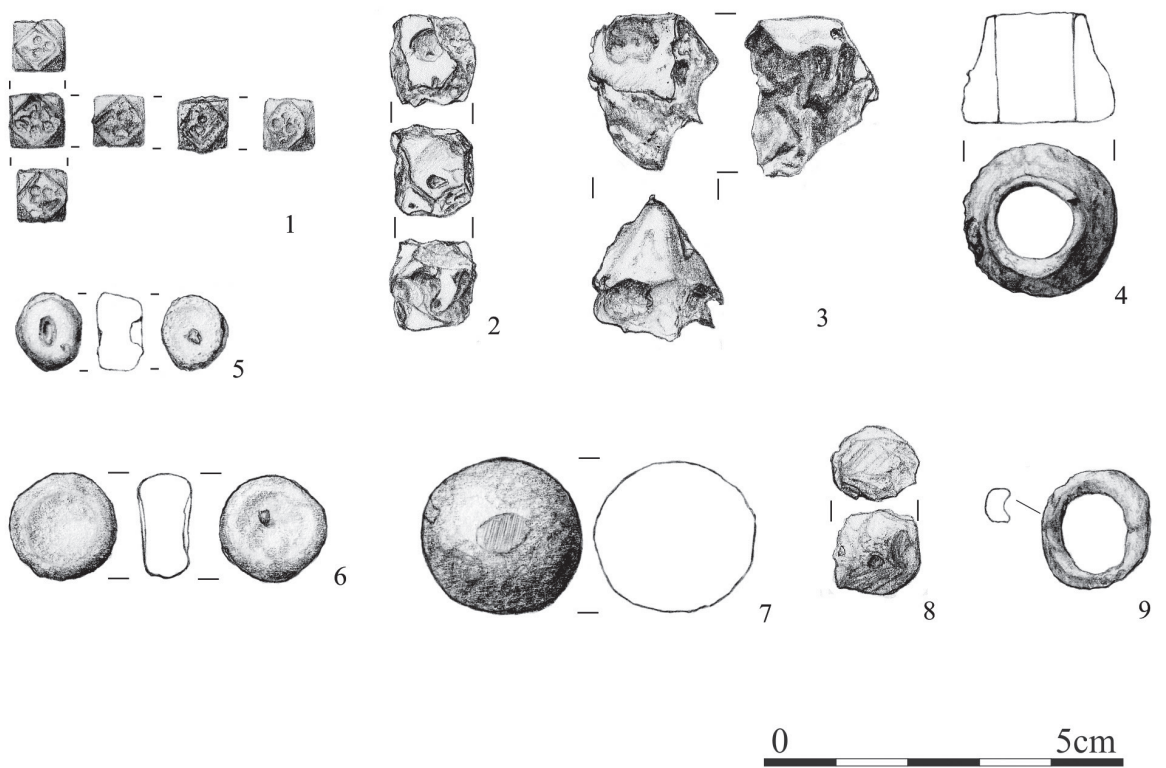

Ryc. 4. Santok stan. 1. Odważniki kubooktaedryczne (1-3), ołowiane (4-6, 9), kulka (7) oraz domniemane jądro odważnika (8). Rys. A. Hurnowicz

Kubooktaedryczny odważnik, o ściance długości $5 \mathrm{~mm}$ i wadze 2,1 g, odlano

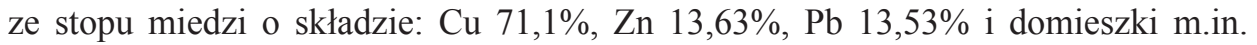
cyny $0,35 \%$ i arsenu $0,54 \%$ (tabela 1 ). Ten stop metali można uznać za mosiądz ołowiowy, zbliżony do składu koszulek pokrywających odważniki kuliste ze spłaszczonymi biegunami typu B 1 znalezione w grodzie santockim. Na kwadratowych ściankach zauważalne są puncowane linie, przy krawędziach, oraz 3 oczka w środku. Reprezentuje on typ A w klasyfikacji Steuera, waży poniżej 4,25 g i należy do najstarszego horyzontu tych odważników pochodzących ze stanowisk z ostatniej ćwierci IX i X stulecia (1997, s. 44-45). Analogicznie znaczone, małe odważniki typu A, znaleziono w dużej ilości w Janowie Pomorskim (dawne Truso), a egzemplarz santocki wpisywałby się w kategorię 3-4, w ogólnym zestawieniu tamtejszych różnych ich wariantów (Steuer 2012, ryc. 6.4). Odważnik z Santoka zachował się w całości i jego ciężar (po wykonanej konserwacji) wynosi 2,1 g, co wraz z oznakowaniem w postaci 3 punktów wpisuje się w system wielkości wagowych ciężarków, stosowany w ośrodkach strefy bałtyckiej oraz obszarach z nią powiązanych (ryc. 5). Przyjmując ciężar odważnika 2,1 g podzielony przez liczbę oczek 3, co daje 0,7 g, otrzymujemy mniej więcej szóstą część podstawowej jednostki o masie 4,25 g lub 4,233 g, określonej dla odważników kubooktaedrycznych w tym systemie (Steuer H. 2012, s. 225). Wielkość 0,71 g i bazowa jednostka 


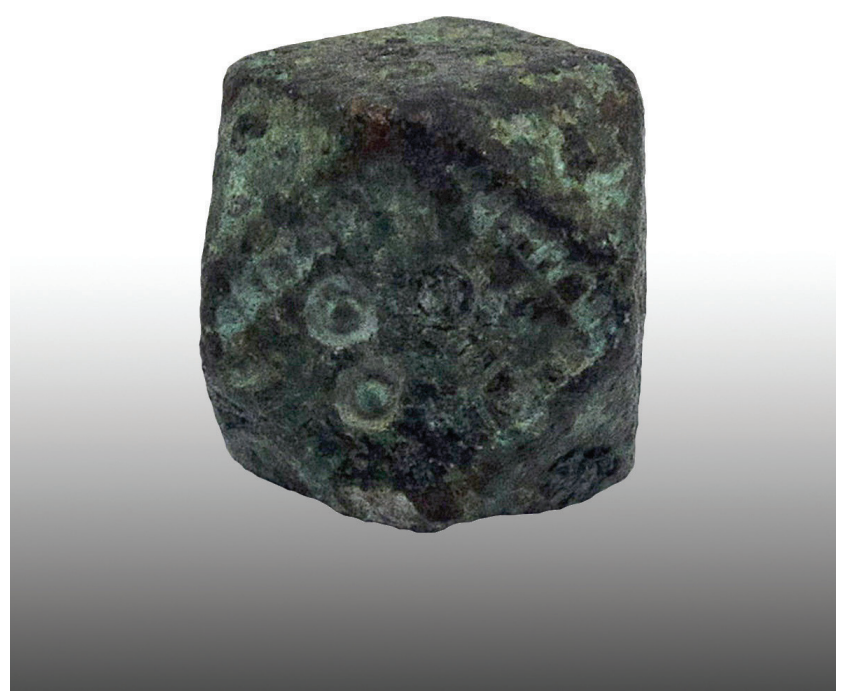

Ryc. 5. Santok, stan. 1. Odważnik kubooktaedryczny znaleziony w obiekcie - „kurhanie” (nr inw. 16/11). Fot. K. Zamelska-Monczak

0,35 g wynikała z podziału jednego dirhema o wadze 2,97 g na mniejsze kawałki. $\mathrm{W}$ systemie tym nadrzędną rolę odgrywało położenie takiego odważnika w całym zestawie takich przyborów.

Również z nawarstwień osadniczych wnętrza grodu tzw. wewnętrznego pochodzą dwa inne odważniki kubooktaedryczne (nr inw. 1188/61; ryc. 4-2, 3) znalezione w warstwie szeroko datowanej na 2 połowę XI-XII wiek. Oba uległy, niestety, znacznemu zniszczeniu przez korozję, dlatego niemożliwe jest określenie ich pierwotnych rozmiarów oraz ciężaru. Mniejszy z odważników ma zachowane na żelaznym jądrze niewielkie pozostałości brązowej koszulki. Szerokość ścianki można określić na 9-10 mm, a zachowana waga to 7,3 g. Z drugiego odważnika przetrwał jedynie nieduży fragment żelaznego jądra z małymi pozostałościami ścianek z brązu. Wysokość odważnika to $22 \mathrm{~mm}$, a zachowany ciężar $15,1 \mathrm{~g}$.

W ośrodku santockim występowały dwa rodzaje odważników kubooktaedrycznych reprezentujących różne, następujące po sobie, etapy ich rozwoju. Najmniejszy egzemplarz przynależy do grupy lekkich i niewielkich, wykonanych ze stopu miedzi z innymi metalami, odważników kubooktaedrycznych, których ciężar nie przekraczał wartości 4,25 g (Steuer 2012, s. 228). Pozostałe dwa odważniki, o większych rozmiarach i wadze powyżej $4,25 \mathrm{~g}$, prezentują już inny standard, także pod względem wykonania. Składają się, podobnie jak egzemplarze kuliste o spłaszczonych 
biegunach, z żelaznego rdzenia powleczonego cienką powłoką ze stopów miedzi. Waga takich odważników mogła sięgać nawet ponad $40 \mathrm{~g}$. Zaobserwowano zmiany w sposobie oznakowania, gdyż zanikły obecne na mniejszych okazach punktowane linie przy krawędziach ścianek i oznaczenia na strefach trójkątnych, a pozostały jedynie układy oczek. W tej grupie odważników występowały także egzemplarze nieoznakowane (Wachowski 2004, s. 360). Takie większe odważniki kubooktaedryczne z Santoka związane są z młodszym horyzontem znalezisk z 2 połowy XI i XII stulecia.

W świetle nowszych ustaleń odważniki o formie kubooktaedrycznej pojawiają się w latach 860-870, jednocześnie z okazami kulistymi o spłaszczonych biegunach, na szerokim obszarze, najliczniej w Europie Północnej i Wschodniej (Steuer 2012, s. 238). Za najstarsze $w$ tej grupie uznaje się małe egzemplarze $\mathrm{z}$ litego brązu o wadze nieprzekraczającej $4,25 \mathrm{~g}$.

Takie najmniejsze odważniki mogły być używane do odważania małych porcji srebra, przy czym funkcjonowały w specjalnych zestawach, którymi dysponował każdy kupiec dokonujący transakcji (Jagodziński 2010, s. 140-141). Uważa się także, że z powodu braku kruszcu mogły one pełnić rolę pieniądza, ekwiwalentu określonej ilości srebra (Jagodziński 2010, s.140-142).

Do grupy takich najmniejszych okazów kubooktaedrycznych należy właśnie niewielki odważnik z Santoka pochodzący z obiektu w formie wielowarstwowego nasypu obwiedzionego drewnianą konstrukcją o chronologii z końca IX-1 połowy $\mathrm{X}$ stulecia. Jego występowanie w Santoku zbiega się ze starszym horyzontem występowania takich przedmiotów w strefie nadbałtyckiej. Należy podkreślić, że w strefie interioru ziem polskich jest to zabytek unikatowy, gdyż najmniejsze z odważników kubooktaedrycznych typu A są znajdowane głównie w ośrodkach powiązanych ze strefą nadbałtycką (np. Truso), a dopiero młodsze ich formy występują w ośrodkach państwa piastowskiego centralnej Wielkopolski (przykładem jest kompleks osadniczy w Gieczu, skąd pochodzi liczny zbiór takich odważników9), a także na Śląsku (Wachowski 2004, s. 360). Na tym tle obecność niewielkiego odważnika kubooktaedrycznego z Santoka może sygnalizować pewien rodzaj kontaktów ze strefą nadbałtycką. Należy dodać, że powiązania ośrodka santockiego ze strefą pomorsko-meklemburską notowane są już od początku jego funkcjonowania i utrzymują się przez cały okres wczesnego średniowiecza (Zamelska-Monczak 2013).

${ }^{9}$ Materiał znany mi z autopsji; serdecznie dziękuję mgr Teresie Krysztofiak, Kierownik Rezerwatu Archeologicznego w Gieczu, za informacje na temat kontekstu znalezienia odważników. 


\section{ODWAŻNIKI OŁOWIANE}

Do zbioru odważników pochodzących z grodu w Santoku zaliczono również cztery egzemplarze odlane $\mathrm{z}$ ołowiu, prezentujące zróżnicowane formy.

Za odważnik uznano ważący $4 \mathrm{~g}$ przedmiot, w kształcie kółka o średnicy $16 \mathrm{~mm}$ (nr inw. 1584/61; ryc. 4-9). Zalegał w warstwach pod humusem, które są datowane na XIII wiek.

Kolejne dwa odważniki ołowiane cechuje zbliżony do cylindrycznego kształt. $\mathrm{Z}$ wnętrza grodu, $\mathrm{z}$ warstwy humusu pochodzi mały, cylindryczny, zachowany kompletnie odważnik (nr inw. 30/17) z ołowiu o wadze 4,2 g (ryc. 4-5). Odważnik wyróżnia oznakowanie umieszczone na obu biegunach w postaci centralnie rozłożonych, płytkich wgłębień o zróżnicowanej szerokości $2,5 \mathrm{~mm}$ i 3,6 mm. Drugi egzemplarz (nr inw. 150/17) zbliżony do formy cylindrycznej jest nieco większy, o wadze 10,1 g. Odważnik nie jest oznakowany, a uwidacznia się lekkie wybrzuszenie jego ścianek oraz nieznaczna wklęsłość biegunów (ryc. 4-6).

Formę największego z ołowianych odważników można określić jako ścięty stożek (nr inw. 136/17). Cechuje go nierówna powierzchnia i asymetryczność (ryc. 4-4). Waga tego odważnika to $24 \mathrm{~g}$, przy wysokości $14,8 \mathrm{~mm}$ i średnicy podstawy $20,9 \mathrm{~mm}$. Odważnik wyróżnia centralnie usytuowany otwór o średnicy 9-10 mm, przebiegający „na wylot” przez całą wysokość stożka. Funkcja otworów występujących w takich odważnikach ołowianych jest nadal kwestią dyskusyjną, co dodatkowo komplikuje fakt, że nie wszystkie egzemplarze w tym kształcie są w nie zaopatrzone. Brak jednoznacznej odpowiedzi na to pytanie sprawia, że przez niektórych badaczy przedmioty te traktowane są jako zwykłe obciążniki o funkcji przęślika (Wachowski 1974, s. 175), ciężarki tkackie czy grzęzidła do sieci rybackich albo piony murarskie (Rozmus 2016, s. 262). Ze stanowisk skandynawskich pochodzą też ołowiane odważniki stożkowate z otworami, który zostały wypełnione masą szklaną, co jest interpretowane jako dekoracja (Pedersen 2008, Fig. 6.36).

Wprawdzie zbiór ołowianych odważników pochodzących z badań prowadzonych na grodzisku w Santoku nie jest liczny, jednak niezwykle zróżnicowany i każdy egzemplarz prezentuje inną formę. Kształty odważników ołowianych, podobnie jak sferyczne i kubooktaedryczne, wyróżniał jednak pewien określony standard. Najliczniejszą grupę tworzą egzemplarze o bryle zbliżonej do walca określane jako cylindryczne, o zróżnicowanych proporcjach, a wśród nich analogiczne do santockich, okazy o lekko wklęsłych podstawach oraz prostych z niewielkim wgłębieniem na jednej z nich. Występują także formy stożkowate. Okazy analogiczne do santockich znane są m.in. z Kaupang (Pedersen 2008, ryc. 6.5, c2 i c3) czy Birki, gdzie odnaleźć je można w wariantach $\mathrm{C}$ i $\mathrm{E}$ w zestawieniu tamtejszych odważników (Kyhlberg 1996, s. 153; ryc. 17:7). Odważniki ołowiane występują także licznie na stanowiskach z ziem polskich. W zestawieniu typologicznym zaproponowanym przez K. Wachowskiego dla zabytków z grodu w Opolu, formy cylin- 
dryczne zaliczono do typu I, natomiast okaz stożkowaty $\mathrm{z}$ otworem do typu C (Wachowski 1974, s. 181, 185).

Ołowiane odważniki były w użyciu bardzo długi okres, gdyż znajdowane są w grobach z VI w., a przeżywały się właściwie do XIV stulecia (Pedersen 2008, s. 11-132).

Intencjonalne wgłębienie w podstawie odważnika interpretowane jest jako oznakowanie, odnoszące się do pozycji egzemplarza w danym zestawie odważników używanym podczas zawierania transakcji. Podobnie wyjaśnia się także oznaczenia na odważnikach kubooktaedrycznych i sferycznych (Gustin 2004, s. 21). Dobry stan zachowania ołowianych odważników umożliwił określenie dokładnego ich ciężaru: 4,1 g i 4,2 g, 10,1 g oraz 24 g. Jest to jednak zbyt mały zbiór, by wnioskować na temat jednostek wagowych, które prezentują. Warto nadmienić jedynie, że w norweskim Kaupang, wśród odważników ołowianych, również występowały właśnie takie cylindryczne o wadze około $4 \mathrm{~g}$, przy czym z jednostką tą korespondowało oznaczenie - jedna puncowana kropka (Pedersen 2008, s. 150-152). Wspomniana jednostka wagowa $4 \mathrm{~g}$ nawiązuje do jednego mitqala arabskiego o wadze 4,245 g, wywodzącego się z systemu islamskiego i stanowiącego 1,5 dirhama.

Wykorzystywanie ołowiu, w postaci brył, placków, a także sztabek ${ }^{10}$, jako środka rozliczeniowego $\mathrm{w}$ transakcjach handlowych jest znanym zjawiskiem, poświadczonym m.in. w źródłach pisanych (Dzieduszycki 1995, s. 99). O stosowaniu ołowiu jako środka płatniczego wśród Chazarów donoszą także relacje kupców arabskich (Lewicka-Rajewska 2004, s. 214).

Do nietypowych przedmiotów, które można zaliczyć do grupy odważników, należy kamienna kulka o średnicy 23 mm i wadze 15,6 g (nr inw. 929/60; ryc. 4-7), znaleziona w nawarstwieniach wnętrza grodu santockiego, datowanych na 4 ćwierć IX wieku. Trudno jednoznacznie przesądzać o funkcji tego zabytku. Powierzchnia kulki jest wyraźnie wygładzona, a jej forma regularna. Używanie kamyków do odważania poświadcza m.in. znalezisko z tzw. grobu kupca na cmentarzysku w Sowinkach, gdzie otoczak znajdował się w zdeponowanym w jamie zestawie odważników (Krzyszowski 1997, s. 644 i Abb. 8-13).

Za domniemaną część odważnika (nr inw. 1090/60; ryc. 4-8) można przyjąć okaz znaleziony we wnętrzu grodu santockiego, w III poziomie osadniczym datowanym na połowę IX wieku. Zalegał w warstwie wiórów i odpadów naniesionych w celu wyrównania terenu między zabudowaniami. Przedmiot sprawia wrażenie zniszczonego na powierzchniach, a przyjmując, iż jest to część odważnika, zachowałoby się jedynie żelazne jądro o wadze 2,5 g. Mógł to być niewielkiego rozmiaru odważnik kubooktaedryczny, skoro zachowana bryłka ma szerokość w przybliżeniu $10 \mathrm{~mm}$. Wątpliwości może jednak budzić występowanie odważni-

${ }^{10}$ Część sztabki ołowianej o wadze 44,7 g znaleziono na grodzisku w Santoku w 2017 roku podczas badań nawarstwień osadniczych datowanych na podstawie materiałów archeologicznych na XI w.; zabytek ten (nr inw. 66/17) jest obecnie poddawany analizie metalograficznej. 
ka w nawarstwieniach z połowy IX w., gdyż w świetle ustaleń poczynionych dla najbliższej w odniesieniu do Santoka strefy nadbałtyckiej, gdzie takie przedmioty koncentrują się w największej ilości, ich obecność zaznacza się dopiero w zespołach z 2 połowy tego stulecia, szczególnie z ostatniej jego ćwierci.

\section{PODSUMOWANIE}

Do zbioru przyborów kupieckich pochodzących ze stanowiska $1 \mathrm{w}$ Santoku (relikty tzw. grodu i podgrodzia), związanych z działalnością handlową, zaliczono części trzech wag oraz zbiór 18 odważników i dwóch przedmiotów z dużym prawdopodobieństwem pełniących funkcję ciężarków wagowych.

Znaleziska wczesnośredniowiecznych monet, odważników czy wag uważa się powszechnie za przedmioty powiązane ze sferą handlu, z ówczesnym systemem płatności. Niestety, w kwestii funkcji takich przedmiotów i sposobów ich wykorzystywania niewiele wnoszą zabytki pochodzące z Santoka oraz kontekst ich znalezienia. Spośród 20 odważników, aż 9 zostało znalezionych w warstwie humusu lub luźno na powierzchni stanowiska.

Dwa odważniki kuliste ze spłaszczonymi biegunami wraz z dwoma fragmentami wag zalegały $\mathrm{w}$ obrębie czternastowiecznego obiektu interpretowanego jako kuźnia. Wystąpiły tam wraz z innymi metalowymi przedmiotami, m.in. fragmentem grawerowanej misy z mosiądzu (Janowski, Zamelska-Monczak 2016), lecz trudno jednoznacznie stwierdzić, choć wydaje się to najbardziej prawdopodobne, że stanowiły surowiec wtórny, przeznaczony do kolejnego przetopienia.

Z obiektami pełniącymi funkcje mieszkalne i gospodarcze można powiązać pięć odważników. Znajdowały się w nawarstwieniach wnętrza budynków drewnianych, wraz z fragmentami ceramiki naczyniowej, kości zwierzęcych oraz innych przedmiotów wyposażenia. W obiektach tych nie natrafiono na inne zabytki, które można ewidentnie powiązać $\mathrm{z}$ dziedziną handlu (w inwentarzu zabytków pochodzących z tych budynków obecne są głównie przedmioty codziennego użytku, takie jak przęśliki gliniane, oprawka z poroża, igła kościana i szydło, noże oraz fragmenty silnie zniszczonych przedmiotów metalowych o nieokreślonej funkcji; dokumentacja z badań w Santoku w Archiwum IAE PAN Ośrodek w Poznaniu). Na tym tle wyjątkowo prezentuje się jedynie wyposażenie obiektu - domostwa $\mathrm{nr} 2 \mathrm{z} 1$ połowy XIII w., odsłoniętego na podgrodziu, w którym znaleziono (domniemany?) odważnik w formie ołowianego kółka o wadze 4,1 g (nr inw. 1584/62). Oprócz odważnika, fragmentów naczyń glinianych i kości zwierzęcych, we wnętrzu budynku znajdowały się przedmioty codziennego użytku, jak igły (2 sztuki), noże (4 egz.), oprawka z poroża, gliniany przęślik, żelazny gwóźdź (też grot bełtu kuszy i liczne ułamki nieokreślonych wyrobów metalowych), ale także wyroby wykonane z surowców ,importowanych": fyllitowa osełka, paciorek ze szkła oraz z karneolu, przęślik z łupku wołyńskiego (wyniki analizy stratygrafii stanowiska nr 1 
w Santoku oraz opracowania materiałów archeologicznych są obecnie przygotowywane do druku). Nasuwa się pytanie, czy przytoczone zabytki obcego pochodzenia i ołowiany odważnik można rzeczywiście łączyć z wymianą towarów i działalnością kupiecką?

Rozpatrując kontekst znalezienia odkrytych w Santoku zabytków związanych z systemem płatniczym i wymianą, należy wspomnieć o małym odważniku kubooktaedrycznym (nr inw. 16/11), w nawarstwień osadniczych wnętrza grodu z 1 połowy X wieku. Wspomniano wcześniej, że odważnik leżał w jednej z warstewek tworzących wielowarstwowy nasyp zbudowany z piasku, spalenizny i kamieni, zamknięty $\mathrm{z}$ trzech stron drewnianym ogrodzeniem (ryc. 6). Całkowitą jego średnicę, przyjmując kolisty kształt obiektu, można określić na 4,5-5 $\mathrm{m}$ na poziomie podstawy. W obrębie nasypu, w jego centralnej części, zachowały się dołki po słupach, które można interpretować jako relikty konstrukcji drewnianej wzniesionej nad tym obiektem: zadaszenia albo samodzielnych elementów nośnych (może na takich słupach umieszczono pewne eksponowane przedmioty?). Dołki występowały w centralnej części nasypu, w miejscu kulminacji. W czterech miejscach znajdowały się skupiska ceramiki, a oprócz odważnika kubooktaedrycznego w nawarstwieniach nasypu znaleziono: przęśliki gliniane (sześć całych i dwa fragmenty), szydła kościane (trzy całe i jeden fragment), dwa półwytwory z poroża, igłę kościaną, dwa grzebienie $z$ poroża oraz dwa fragmenty okładziny i jedną płytkę skrajną, dwie osełki zachowane fragmentarycznie, w tym jedną $\mathrm{z}$ fyllitu, krążek z piaskowca kamień ze śladami wygładzania, a także dwie oprawki (z kości i z poroża) oraz skamielinę - belemnit ${ }^{11}$. Funkcja tego obiektu nie jest jednoznaczna, a interpretacja pozostaje nadal kwestią otwartą. Obiekty w formie kurhanów i nasypów są znane we wczesnym średniowieczu i występowały w różnych wariantach. Można je wiązać też z miejscami kultu, tzw. otwartymi sanktuariami, nawiązującymi do skandynawskich obiektów zwanych „hörgr” - kopców i ołtarzy z kamieni lub bruków, które z czasem przyjęły formę zadaszoną lub zabudowaną na kształt niewielkiej świątyni (Słupecki 2010, s. 329). Idea ta nie ogranicza się tylko do obszarów objętych wpływami skandynawskimi. Wzór kurhanu z elementami kamiennymi w części nasypu czy wybrukowania pojawia się w starszych fazach wczesnego średniowiecza w Wielkopolsce, choć sama idea ma dużo starsze tradycje jeszcze z okresu wpływów rzymskich i z terenów germańskich (Kara 2009, s. 108-109, ryc. 21A). Mimo że nie została dotąd potwierdzona sepulkralna funkcja obiektu z Santoka, widocznych jest wiele elementów, jak choćby struktura i rozmiary nasypu, obecność drewnianego ogrodzenia czy usytuowanie pagórka w specjalnej strefie w obrębie grodu, skłaniających do łączenia wspomnianego „kurhanu” ze sferą sakralną i obrzędową. Przedstawiony powyżej kontekst znalezienia odważnika kubooktaedrycznego można więc rozpatrywać również jako

${ }^{11}$ Należy zaznaczyć, że obiekt ten został zbadany częściowo, w dwóch etapach: w trakcie prac w latach 1958-1965 oraz 2011-2012. 


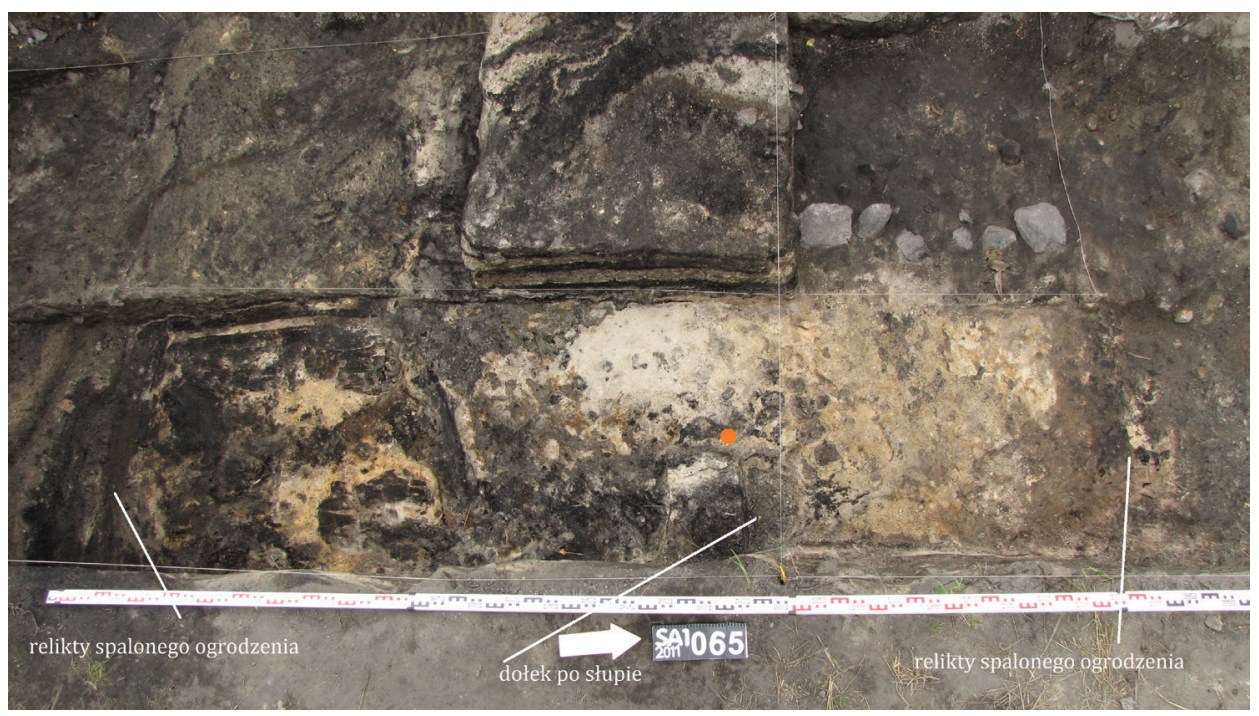

Ryc. 6. Santok, stan. 1. Obiekt w formie nasypu (kurhan?) odsłonięty w wykopie V, ar 297C. Kropka - miejsce znalezienia odważnika. Fot. K. Zamelska-Monczak

powiązany z tą dziedziną aktywności ówczesnej społeczności. O znaczeniu magicznym takich ciężarków dodatkowo świadczy traktowanie ich jako amuletów (Duczko 2016, s. 143). Motyw i forma odważnika kubooktaedryczngo była także wykorzystywana jako element zdobniczy (?) przy wyrobie zapinek i naramienników (Duczko 2016, s. 143).

Przyglądając się w szerszym kontekście obecności utensyliów kupieckich w Santoku, na tle sytuacji ekonomicznej i modelu gospodarki funkcjonującego w tej części interioru, uwagę zwraca fakt, że świadectwa wymiany dóbr pojawiają się tam wcześniej niż w innych strefach Wielkopolski. Wprawdzie znaleziska najstarszych odważników santockich możemy datować na 2 połowę IX stulecia i początek wieku $X$, jednak już wcześniej docierały tam wyroby, które mogły stanowić ekwiwalent w wymianie lub efekt transakcji. Szklane paciorki i bursztyn w formie gotowych przedmiotów oraz grudek surowca występuje w Santoku już od 1 połowy IX w., a obok tego znajdowane są ewidentne luksusowe wyroby obcego pochodzenia, takie jak grzebienie z poroża czy wełniane tkaniny (Zamelska-Monczak 2013).

Wiek IX to okres rozkwitu nadbałtyckiej strefy gospodarczej, w której rozwinął się model handlu i gospodarki wymagający precyzyjnego odważania, co zapewniały stosunkowo dokładnie wyważone odważniki oraz wagi. Ośrodek w Santoku, umiejscowiony wprawdzie w dużej odległości od wybrzeża morskiego, w przestrzeni jawiącej się bardziej jako pogranicze strefy pomorskiej, w świetle źródeł 
archeologicznych przynależał już wtedy z pewnością do ekonomicznej strefy nadbałtyckiej, objętej handlem tranzytowym między północno-zachodnią Europą a Bliskim i Środkowym Wschodem (Adamczyk 2002, s. 64-65). Na obszarze ziem polskich ludzie trudniący się wymianą i pozyskiwaniem surowców mogli docierać w głąb interioru już w IX stuleciu, penetrując tereny Pomorza i przemieszczając się głównie ciekami wodnymi, tworzącymi na tym obszarze niezwykle bogatą sieć połączeń (Łosiński 2008, s. 132). Nie jest przypadkiem, że liczne zbiory odważników znajdowane są $\mathrm{w}$ ośrodkach kojarzonych $\mathrm{z}$ wymianą dalekosiężną, położonych w węzłowych punktach ze względu na wodne i lądowe połączenia komunikacyjne. Odpowiednim przykładem takiej lokalizacji jest wczesnośredniowieczny kompleks osadniczy skupiony wokół Góry św. Wawrzyńca w Kałdusie koło Chełmna, ulokowany w sąsiedztwie przeprawy przez Wisłę. Miejsce to było wykorzystywane przez kilka stuleci, od 2 połowy VII po XIII wiek (Bojarski, Chudziak i Weinkauf 2017, s. 304). Pochodzący z tego stanowiska bogaty zbiór utensyliów kupieckich, fragmentów wag i odważników, związany jest z okresem X-XIII w., gdy ośrodek ten spełniał funkcje ponadregionalnego centrum wymiany (Bojarski, Chudziak, Weinkauf 2017, s. 307). Znalezione odważniki, podobnie jak okazy z Santoka, prezentują zróżnicowany zbiór i obejmują formy: kuliste ze spłaszczonymi biegunami, kubooktaedryczne, także żelazne i ołowiane o różnym kształcie. Ze sferą wymiany i handlem dalekosiężnym odbywającym się w strefie pogranicza wielkopolsko-pomorskiego powiązany jest natomiast kompleks grodowy w Pawłówku, skąd pochodzi bogaty zestaw odważników i fragmentów wag (Chudziak, Błędowski 2017, s. 321-323, ryc. 10). Niezwykle liczny zbiór utensyliów kupieckich został znaleziony w nawarstwieniach obiektów zarejestrowanych w obrębie członów dawnego grodu, który, w świetle ostatnich ustaleń, funkcjonował w 2 połowie XI i początku XII wieku (Chudziak, Błędowski 2017, s. 321). Ośrodek w Pawłówku powiązany byłby z tym samym co Santok traktem o układzie równoleżnikowym przebiegającym wzdłuż Warty-Noteci, łączącym dorzecza Odry i Wisły, lecz osiedle santockie wyróżnia się dużo starszą metryką.

Mieszkańcy Santoka korzystali nieprzerwanie z umiejscowienia na trasie komunikacyjnej i handlowej właściwie przez cały czas funkcjonowania osady, a potem grodu. W kolejnych poziomach osadniczych, począwszy od 2 połowy IX aż do XIV w. występują przedmioty związane z ówczesnym systemem płatniczym, czyli wagi składane i odważniki. Najstarszy fragment składanej wagi szalkowej pochodzi z XI w., a kolejne egzemplarze znaleziono przy kuźni datowanej na XIV stulecie. Spośród odważników za najstarsze egzemplarze można uznać okaz kubooktaedryczny znaleziony w nawarstwieniach z wnętrza grodu z 1 połowy (początku?) $\mathrm{X}$ wieku. Dwa pozostałe odważniki tego typu pochodzą $\mathrm{z}$ obiektów XI-wiecznych. Okazy kuliste ze spłaszczonymi biegunami, określane jako beczułkowate, występowały w poziomach datowanych na 1 połowę X w. oraz od XII do XIV stulecia. Odważniki ołowiane obecne są w nawarstwieniach datowanych od XI do XIII wieku. 
Santok położony był przy jednej z ważniejszych ówczesnych arterii wodnych Warta-Noteć, spinającej kilka regionów, a przede wszystkim łączącej dorzecza Odry i Wisły, miał wszelkie predyspozycje, by odegrać ważną rolę - punktu obsługi na tej trasie oraz centrum kontroli i czerpania zysków z lokalizacji na szlaku handlowym.

\section{BIBLIOGRAFIA:}

Adamczyk D. 2002, Orientalno-baltycki system handlowy a proces ksztaltowania się Europy Wschodniej w IX-X wieku, „Średniowiecze Polskie i Powszechne” 2, s. 63-88.

Bojarski J., Chudziak W., Weinkauf M. 2017, Góra Św. Wawrzyńca we wczesnym średniowieczu - na skrzyżowaniu szlaków dalekosiężnych, w: Pradoliny pomorskich rzek. Kontakty kulturowe i handlowe w pradziejach i wczesnym średniowieczu, M. Fudziński, W. Świętosławski, W. Chudziak (red.), Gdańsk, s. 301-313.

Chudziak W. 2014, Balances and weights, w: The Island in Żótte on Lake Zarańskie. Early Medieval Gateway into West Pomerania, W. Chudziak, R. Kaźmierczak (ed.), Toruń, s. 273-277.

Chudziak W., Błędowski P. 2017, Wczesnośredniowieczny zespót osadniczy w Pawłówku - „wrota” do Pomorza Wschodniego, w: Pradoliny pomorskich rzek. Kontakty kulturowe $i$ handlowe $w$ pradziejach $i$ wczesnym średniowieczu, M. Fudziński, W. Świętosławski, W. Chudziak (red.), Gdańsk, s. 315-325.

Chudziak W., Kaźmierczak R., Conclusions, w: The Island in Żótte on Lake Zarańskie. Early Medieval Gateway into West Pomerania, W. Chudziak, R. Kaźmierczak (ed.), Toruń, s. 451-453.

Dzieduszycki W. 1995, Kruszce w systemach wartości i wymiany społeczeństwa Polski wczesnośredniowiecznej, Poznań.

Gustin I. 2004, Coins and Weights from the Excavations 1990-1995. An Introduction and Presentation of the Material, w: Excavations in the Black Earth 1990-1995. Eastern Connections. Part Two: Numismatics and Methrology. Birka Studies 6, s. 11-25.

Jagodziński A. 2010, Truso między Weonodlandem a Witlandem, Elbląg.

Janowski A., Zamelska-Monczak K. 2016, Sacrum - Profanum. Dwa żywoty misy mosiężnej z Santoka, „Slavia Antiqua”, 57, s. 199-219.

Kara M. 1998, Wczesnośredniowieczny grób uzbrojonego kupca z miejscowości Ciepłe na Pomorzu Gdańskim w świetle ponownej analizy chronologicznej, w: H. Kočka-Krenz, W. Łosiński (red.), Kraje stowiańskie w wiekach średnich. Profanum i sacrum, Poznań, s. 496-504.

- 2009, Najstarsze państwo Piastów - rezultat przełomu czy kontynuacji? Studium archeologiczne. Poznań.

- 2016, Przybory kupieckie, w: A. Buko (red.) Bodzia. Elitarny cmentarz z początków państwa polskiego, Warszawa, s. 107-113.

Kronika Wielkopolska 1965, Kronika Wielkopolska, przekład K. Abgarowicz, Warszawa.

Krzyszowski A. 1997, Frühmittelalterliches Grab eines Kaufmannes aus Sowinki, „Germania” 75-2, s. $639-667$

Kurnatowska Z. 1995, Grody santockie w świetle dotychczasowych badań archeologicznych, w: Santok - poczatki grodu. Materiały z sesji historycznej, Gorzów Wlkp., s. 10-22.

Kylhberg O. 1986, Die Gewichte in den Gräbern von Birka - Metrologie und Wirtschaft, w: G. Arwidsson (ed.) Birka II:2. Systematische Analysen der Gräberfeld, Stockholm, s. 147-162.

Leciejewicz L. 1978, Gród i podgrodzie u Stowian Zachodnich - problemy funkcji i rozwiazań przestrzennych, Prace Naukowe Instytutu Historii Architektury, Sztuki i Techniki Politechniki Wrocławskiej, 12, s. 15-57.

Lewicka-Rajewska U. 2004, Arabskie opisanie Stowian. Źródła do dziejów średniowiecznej kultury, Wrocław. 
Łosiński W. 2008, Pomorze Zachodnie we wczesnym średniowieczu. Studium archeologiczne, Poznań.

Maleszka M. 1998, Zespół odważników ze stanowiska wczesnośredniowiecznego we Wrześnicy, gm. Stawno, woj. stupskie, w: M. Dworaczyk, P. Krajewski, E. Wilgocki (red.), XII Sesja Pomorzoznawcza, Szczecin, 23-24 października 1997 r. Materiały, „Acta Archaeologica Pomoranica” 1, s. 177-184.

Pedersen U. 2008, Weights and balances, w: D. Skre (ed.), Means of Exchange. Dealing with Silver in the Viking Age, „Kaupang Excavation Project Publication Series” 2, Norske Oldfunn, Oslo, s. 119-195.

Rozmus D. 2016, Nowe znaleziska wczesnośredniowiecznych ciężarków ołowianych, „Materiały Archeologiczne" 41, s. 263-267.

Sindbæk S. M. 2001, An Object of Exchange Brass Bars and the Routinization of Viking Age Long-Distance Exchange in the Baltic Area, Offa 58, s. 49-60.

Słupecki L.P. 1994, Slavonic Pagan Sanctuaries, Warszawa.

Steuer H. 1997, Waagen und Gewichte aus dem mittelalterlichen Schleswig. Funde des 11. bis 13. Jahrhunderts aus Europa als Quellen zur Handels- und Währungsgeschichte, Köln.

- 2012 VI. Wagi i odważniki wagowe z Janowa, w: Brather S. und Jagodziński M. (ed.), Nadmorska osada handlowa z okresu wikingów z Janowa (Truso). Badania geofizyczne, archeo-pedologiczne $i$ archeologiczne w latach 2004-2008, Bonn, s. 185-282.

Tomaszewska-Szewczyk A. 2016, Mosiądz w starożytności i średniowieczu. Przyczynek do dziejów kultury materialnej, AUNC. Zabytkoznawstwo i Konserwatorstwo 47, s. 7-41.

Wachowski K. 1974, Wagi i odważniki na Śląsku wczesnośredniowiecznym na tle porównawczym, „Przegląd Archeologiczny" 22, s. 173-207.

- 2002, Przybory kupieckie ze Starego Miasta we Wrocławiu, w: J. Piekalski (red.) Rynek wrocławski w świetle badań archeologicznych, cz. 2, „Wratislavia Antiqua” 5, Wrocław, s. 277- 286.

Wärmländer S., Zoric D., Byockd Dawid., Scots D. A. 2010, Metallurgical findings from a Viking Age chieftain's farm in Iceland, „Journal of Archaeological Science” 37, s. 2284-2290.

Zamelska-Monczak K. 2009 Początki Santoka w świetle nowszych ustaleń archeologicznych, w: B. Gruszka (red.), Ad Oderam fluvium. Księga dedykowana pamięci Edwarda Dąbrowskiego, Zielona Góra, s. $99-109$.

- 2012, Przemiany spoleczno-kulturowe w okresie formowania się państwa piastowskiego $w$ Wielkopolsce pótnocno-zachodniej, na podstawie materiałów archeologicznych z Santoka i Międzyrzecza (autoreferat wygłoszony w trakcie obrony pracy doktorskiej w dniu 8 kwietnia 2009 r.), „Folia Praehistorica Posnaniensia" 14, s. 371-380.

- 2013, Traces of Viking culture in Santok, w: (ed.), S. Moździoch, B. Stanisławski, P. Widzewski, Scandinavian Culture in Medieval Poland, Seria: Interdisciplinary Medieval Studies, Volume II, Wrocław, p. 267-277.

Źródło internetowe:

http://web.comhem.se/vikingbronze/casting.htm

Anders Söderberg Scandinavian bronzecasting in the Viking Age and the Early Middle Ages 